\title{
Bioaccessibility and Bioactivity of Cereal Polyphenols: A Review
}

\author{
Borkwei Ed Nignpense ${ }^{1}\left(\mathbb{D}\right.$, Nidhish Francis ${ }^{1,2}(\mathbb{D})$, Christopher Blanchard ${ }^{1,3}$ and \\ Abishek Bommannan Santhakumar 1,3,*(D)
}

1 School of Biomedical Sciences, Charles Sturt University, Locked Bag 588, Wagga Wagga, NSW 2678, Australia; bednignpense@csu.edu.au (B.E.N.); nfrancis@csu.edu.au (N.F.); cblanchard@csu.edu.au (C.B.)

2 School of Animal and Veterinary Sciences, Charles Sturt University, Wagga Wagga, NSW 2650, Australia

3 Australian Research Council (ARC), Industrial Transformation Training Centre (ITTC) for Functional Grains, Graham Centre for Agricultural Innovation, Charles Sturt University, Wagga Wagga, NSW 2650, Australia

* Correspondence: asanthakumar@csu.edu.au; Tel.: +61-2-6933-2678

Citation: Ed Nignpense, B.; Francis, N.; Blanchard, C.; Santhakumar, A.B. Bioaccessibility and Bioactivity of Cereal Polyphenols: A Review. Foods 2021, 10, 1595. https://doi.org/ 10.3390 /foods 10071595

Academic Editor:

Antonella Pasqualone

Received: 7 June 2021

Accepted: 7 July 2021

Published: 9 July 2021

Publisher's Note: MDPI stays neutral with regard to jurisdictional claims in published maps and institutional affiliations.

Copyright: (c) 2021 by the authors. Licensee MDPI, Basel, Switzerland. This article is an open access article distributed under the terms and conditions of the Creative Commons Attribution (CC BY) license (https:// creativecommons.org/licenses/by/ $4.0 /)$.

\begin{abstract}
Cereal bioactive compounds, especially polyphenols, are known to possess a wide range of disease preventive properties that are attributed to their antioxidant and anti-inflammatory activity. However, due to their low plasma concentrations after oral intake, there is controversy regarding their therapeutic benefits in vivo. Within the gastrointestinal tract, some cereal polyphenols are absorbed in the small intestine, with the majority accumulating and metabolised by the colonic microbiota. Chemical and enzymatic processes occurring during gastrointestinal digestion modulate the bioactivity and bioaccessibility of phenolic compounds. The interactions between the cereal polyphenols and the intestinal epithelium allow the modulation of intestinal barrier function through antioxidant, anti-inflammatory activity and mucin production thereby improving intestinal health. The intestinal microbiota is believed to have a reciprocal interaction with polyphenols, wherein the microbiome produces bioactive and bioaccessible phenolic metabolites and the phenolic compound, in turn, modifies the microbiome composition favourably. Thus, the microbiome presents a key link between polyphenol consumption and the health benefits observed in metabolic conditions in numerous studies. This review will explore the therapeutic value of cereal polyphenols in conjunction with their bioaccessibility, impact on intestinal barrier function and interaction with the microbiome coupled with plasma anti-inflammatory effects.
\end{abstract}

Keywords: cereal polyphenols; bioaccessibility; bioavailability; microbiota; intestinal barrier function; inflammation; oxidative stress

\section{Introduction}

Cereals such as wheat, rice, oats, barley and sorghum are grown and consumed as staple diets globally [1]. Cereals are edible seeds or grains of the grass family, Gramineae that have structural similarities: an outer bran layer, endosperm and embryo [1]. Whole grains contain all of these three components whereas refined grains only have the endosperm [1]. Consumption of whole-grain cereals has been linked to a significant reduction in chronic diseases [2]. With the increase in chronic conditions such as obesity in developed countries and malnutrition in developing countries, cereal grains, due to their health benefits and affordability, provide nutritional value and food security, respectively. Substantial research has attributed the health benefits to bioactive compounds in whole grains, particularly micronutrients such as polyphenols.

Polyphenols are plant-based compounds (found in fruits, vegetables and grains) that have demonstrated bioactive properties including antithrombotic, anti-inflammatory and antioxidant properties both in vitro and in vivo [3-6]. They are a large group of heterogeneous compounds characterized by their basic structure consisting of a benzene ring with hydroxyl constituents [7]. For example, flavonoids, specific groups of polyphenols 
with $\mathrm{A}, \mathrm{B}$ and $\mathrm{C}$ aromatic rings, exert antioxidant activity dependent on the functional groups attached and the degree of hydroxylation on the rings [8]. Among cereal grains, the phenolic composition may vary due to many factors such as environmental conditions, variety and pigmentation [9-11]. It is believed these polyphenols target pathways of inflammation through their antioxidant, metal-chelating and gene regulatory activities [12].

A study by Callcott et al. [13] demonstrated that consumption of pigmented rice alleviates plasma inflammatory markers in obese participants. The coloured rice, rich in anthocyanin - the polyphenol responsible for pigmentation-also displayed strong antioxidant and anti-inflammatory activity in vitro and ex vivo [14]. Unlike some other polyphenols, anthocyanins have a relatively higher bioaccessibility (the amount available for absorption) in the stomach and this may explain the systemic anti-inflammatory and antioxidant effects observed following acute consumption [15-17]. However, although the mode of action of polyphenols in vitro seem to correlate with in vivo findings, there is controversy surrounding bioavailability i.e., optimal physiological concentrations attainable in vivo that results in favourable biological activity (bioactivity) [18]. Following ingestion, gastrointestinal digestion and colonic bacterial metabolism are likely to significantly impact the bioaccessibility and bioavailability of the cereal polyphenols. For this reason, understanding the interaction between polyphenols and the intestinal milieu will help elucidate the positive health outcomes observed with consumption of polyphenol-rich cereals. Although studies in the past have attempted to investigate this interaction using polyphenols from various other food sources, an understanding of the role of cereal polyphenols is limited [19-22]. This review will provide an overview of the role of gastrointestinal (GI) digestion in the modulation of cereal polyphenol bioavailability. The impact cereal polyphenols may have on intestinal health and inflammation will be discussed by evaluating studies on dietary polyphenol bioaccessibility, the impact on intestinal barrier function, gut microbiome, and the associated antioxidant and anti-inflammatory plasma effects.

\section{Cereal Polyphenols}

The common phenolic compounds found in cereals include flavonoids and phenolic acids, classified as hydroxybenzoic or hydroxycinnamic acids [10]. Some phenolic compounds are rare and highly specific to a few cereal grains. Some examples include the 3-deoxyanthocyanin found in sorghum and avenanthramides found in oats [23]. The biological effects of these phenolic extracts can be attributed to their structure-activity relationships. Hydroxybenzoic and hydroxycinnamic acids possess free radical scavenging ability due to their polarity and hydroxyl groups (Table 1). One of the most abundant phenolic acids in cereals, ferulic acid, has one hydrogen atom from its hydroxyl group that can react with a free radical to exhibit antioxidant activity [10]. Other phenolic acids such as protocatechuic acid and caffeic acid exhibit antioxidant effects due to the resonance stabilization created by the presence of two hydroxyl groups in the ortho position [24-26]. However, depending on their electrochemical behaviour and oxidation potentials, Simić et al. [25] have shown that phenolic acids may act as either prooxidants or antioxidants. According to this study, the flavonols quercetin and rutin (quercetin-3-rutinoside), found in Buckwheat, demonstrate antioxidant activities which may be attributed to their structural features [27]. The antioxidant activity of quercetin and rutin is likely to be due to hydroxyls present at the $\mathrm{C}-3^{\prime}, 4^{\prime}$ positions in the $\mathrm{B}$ ring [8]. 
Table 1. Basic structures of common phenolic compounds found in cereals.

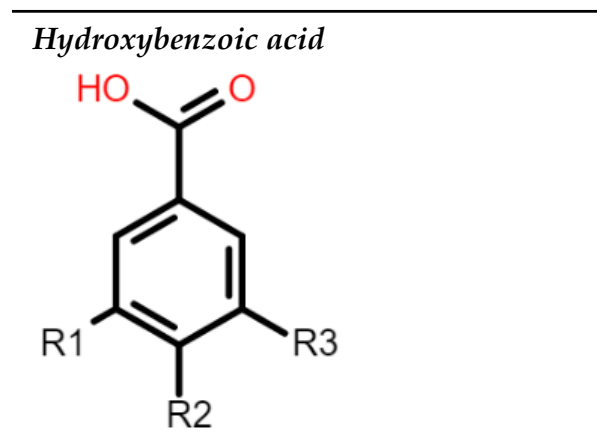

Gallic acid: $\mathrm{R} 1=\mathrm{OH} ; \mathrm{R} 2=\mathrm{OH} ; \mathrm{R} 3=\mathrm{OH}$

Protocatechuic acid: $\mathrm{R} 1=\mathrm{OH} ; \mathrm{R} 2=\mathrm{OH} ; \mathrm{R} 3=\mathrm{H}$

Vanillic acid: $\mathrm{R} 1=\mathrm{OH} ; \mathrm{R} 2=\mathrm{OCH}_{3} ; \mathrm{R} 3=\mathrm{H}$

Hydrobenzoic acid: $\mathrm{R} 1=\mathrm{H} ; \mathrm{R} 2=\mathrm{OH} ; \mathrm{R} 3=\mathrm{H}$

\section{Flavonoid backbone}

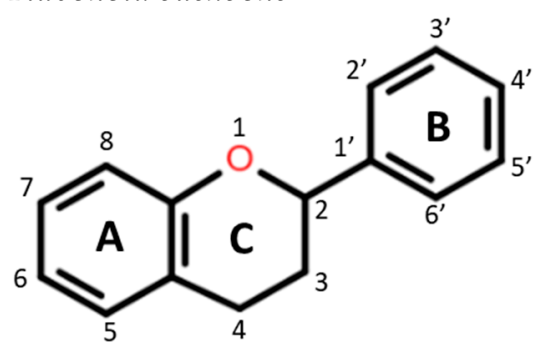

Flavanones: $\mathrm{C} 4$ keto group

Flavanols: C4 keto group, C3 hydroxyl group

Flavones: C2-C3 double bond, $\mathrm{C} 4$ keto group

Flavan-3-ols: C3-hydroxyl group

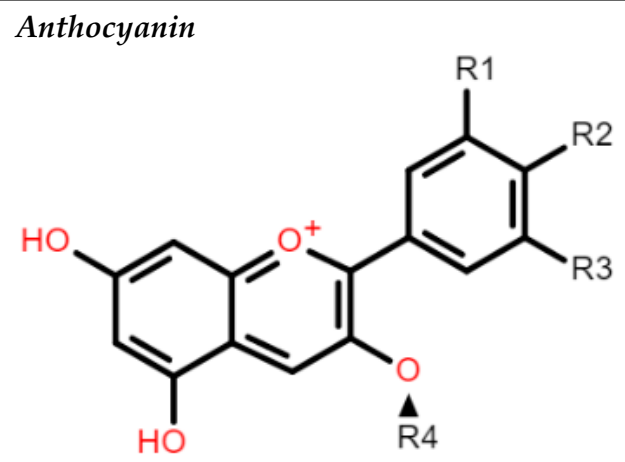

Cyanidin 3-glucoside: $\mathrm{R} 1=\mathrm{OH} ; \mathrm{R} 2=\mathrm{OH} ; \mathrm{R} 3=\mathrm{H} ; \mathrm{R} 4=$

O- $\beta$-D-glucoside

Delphinidin 3-glucoside: $\mathrm{R} 1=\mathrm{OH} ; \mathrm{R} 2=\mathrm{OH} ; \mathrm{R} 3=\mathrm{OH} ; \mathrm{R} 4=$

O- $\beta$-D-glucoside

Peonidin 3-glucoside: $\mathrm{R} 1=\mathrm{OCH}_{3} ; \mathrm{R} 2=\mathrm{OH} ; \mathrm{R} 3=\mathrm{H} ; \mathrm{R} 4=$

O- $\beta$-D-glucoside

Petunidin 3-glucoside: $\mathrm{R} 1=\mathrm{OH} ; \mathrm{R} 2=\mathrm{OH} ; \mathrm{R} 3=\mathrm{OCH}_{3} ; \mathrm{R} 4=$

O- $\beta$-D-glucoside

Malvidin 3-glucoside: $\mathrm{R} 1=\mathrm{OCH}_{3} ; \mathrm{R} 2=\mathrm{OH} ; \mathrm{R} 3=\mathrm{OCH}_{3} ; \mathrm{R} 4=$

O- $\beta$-D-glucoside

Pelargonidin 3-glucoside: $\mathrm{R} 1=\mathrm{H} ; \mathrm{R} 2=\mathrm{OH} ; \mathrm{R} 3=\mathrm{H}$; R4 =

O- $\beta$-D-glucoside

\section{Hydroxycinnamic acid}<smiles>[R2]c1ccc(/C=C/C(=O)O)cc1[R2]</smiles>

Caffeic acid: $\mathrm{R} 1=\mathrm{OH} ; \mathrm{R} 2=\mathrm{OH}$

Ferulic acid: $\mathrm{R} 1=\mathrm{OCH}_{3} ; \mathrm{R} 2=\mathrm{OH}$

p-coumaric acid: $\mathrm{R} 1=\mathrm{H} ; \mathrm{R} 2=\mathrm{OH}$

\section{Flavonol}<smiles>[R]c1c(-c2ccc(O)c(O)c2)oc2cc(O)cc(O)c2c1=O</smiles>

Quercetin: $\mathrm{R} 1=\mathrm{OH}$

Rutin (quercetin 3-O glucoside): R1 = O- $\beta$-D-rutinoside

\section{3-Deoxyanthocyanidin}<smiles>[R1]c1cc(C2=[O+]C3C=C(O)C=C(O)C3C=C2)ccc1O</smiles>

Apigeninidin: $\mathrm{R} 1=\mathrm{H}$

Luteolinidin: $\mathrm{R} 1=\mathrm{OH}$ 
Table 1. Cont.

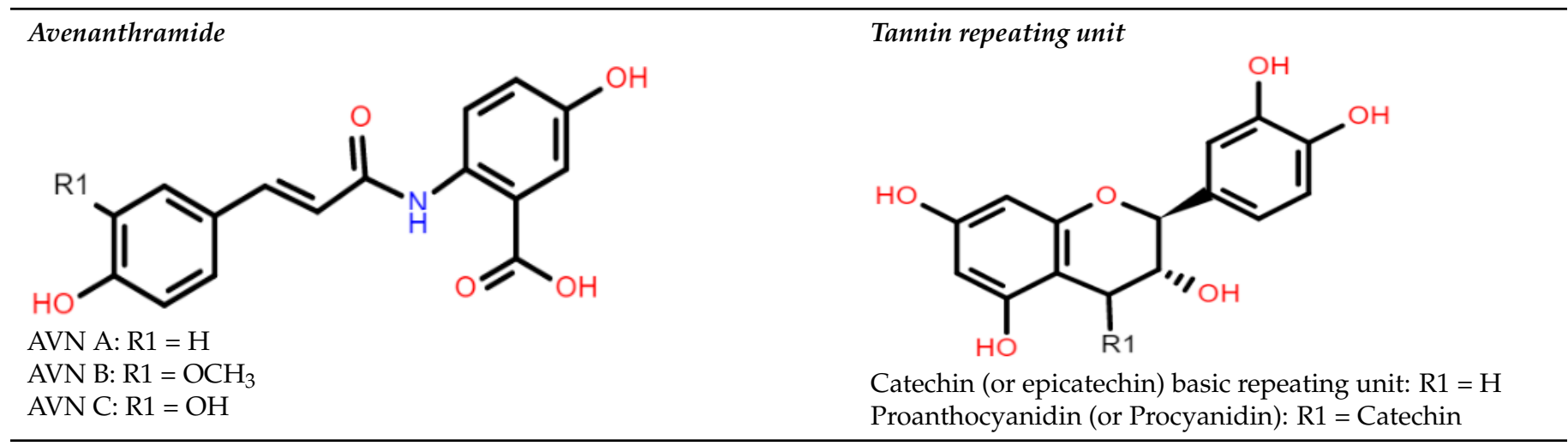

Flavonoids contain functional groups that enhance both antioxidant and anti-inflammatory activity [28]. Flavones such as apigenin possess the 2,3-double bond and 4-keto group of the $C$ ring that contribute to their antioxidant and anti-inflammatory activity and enhance affinity to target protein receptors [28]. Flavonoid glycosides such as cyanidin 3-glucosides exhibit antioxidant and anti-inflammatory activity and can be absorbed intact from the GI tract but with low bioavailability (1-100 nmol/L of total anthocyanin plasma concentration following doses of $0.7-10.9 \mathrm{mg} / \mathrm{kg}$ in human studies) $[29,30]$. On the other hand, the phenolic compound avenanthramide (AVN) is a conjugate of phenolic acid and an anthranilic acid and is known to have a relatively higher bioavailability $(374.6 \mathrm{nmol} / \mathrm{L}$ of total AVN plasma concentration following $1 \mathrm{~g}$ avenanthramide-enriched mixture from oats) [31,32]. There are numerous AVN forms but AVN A, AVN B and AVN C are the main types (Table 1) Among the AVNs, AVN C exhibits the strongest antioxidant activity. AVN C requires a $0.074 \mu$ moles concentration to achieve a $50 \%$ reduction in the free radical 2,2-diphenyl1-picrylhy-drazyl compared to $0.198 \mu$ moles and $0.105 \mu$ moles concentration required by AVN A and AVN B, respectively [33]. This is likely to be due to the free radical scavenging of the 2-hydroxyl groups on the phenolic acid aromatic ring [31,34]. However, most of these structure-activity studies on cereal polyphenols have been undertaken in vitro and thus may not reflect the bioactivity observed in vivo especially after cereals undergo GI digestion.

\subsection{GI Digestion of Cereal Polyphenols}

\subsubsection{Oral and Gastric Digestion}

Cereal grains when ingested travel first through the GI tract before being metabolised further by the liver and then entering the systemic circulation (Figure 1). During mastication in the oral cavity, chewing and salivary amylase break down the starch, mechanically and chemically, within the cereal matrix into a bolus [35]. The polyphenol-containing bolus then travels to the stomach where it undergoes gastric digestion involving gastric juice containing hydrochloric acid, pepsin, lipase, mucus, electrolytes and water [35]. Hydrochloric acid contributes to an acidic $\mathrm{pH}$ environment in the range of 1.3 to 2.5 that favours the denaturation of cereal peptides [36,37]. Some polymeric polyphenols such as procyanidins can be degraded into smaller units during gastric digestion, but there is limited information on the impact gastric digestion has on the bioactivity of cereal polyphenols [38]. Absorption of polyphenols in the stomach is limited yet some anthocyanin glycosides may be absorbed quickly in the gastric phase possibly through a bili-translocase, an organic anion membrane transporter, and appear in the bloodstream [16,39]. Evaluation of the structure-activity relationship of mono- and di-glucosyl anthocyanins reveals that they are better ligands for the bili-translocase than their corresponding aglycones [39]. 


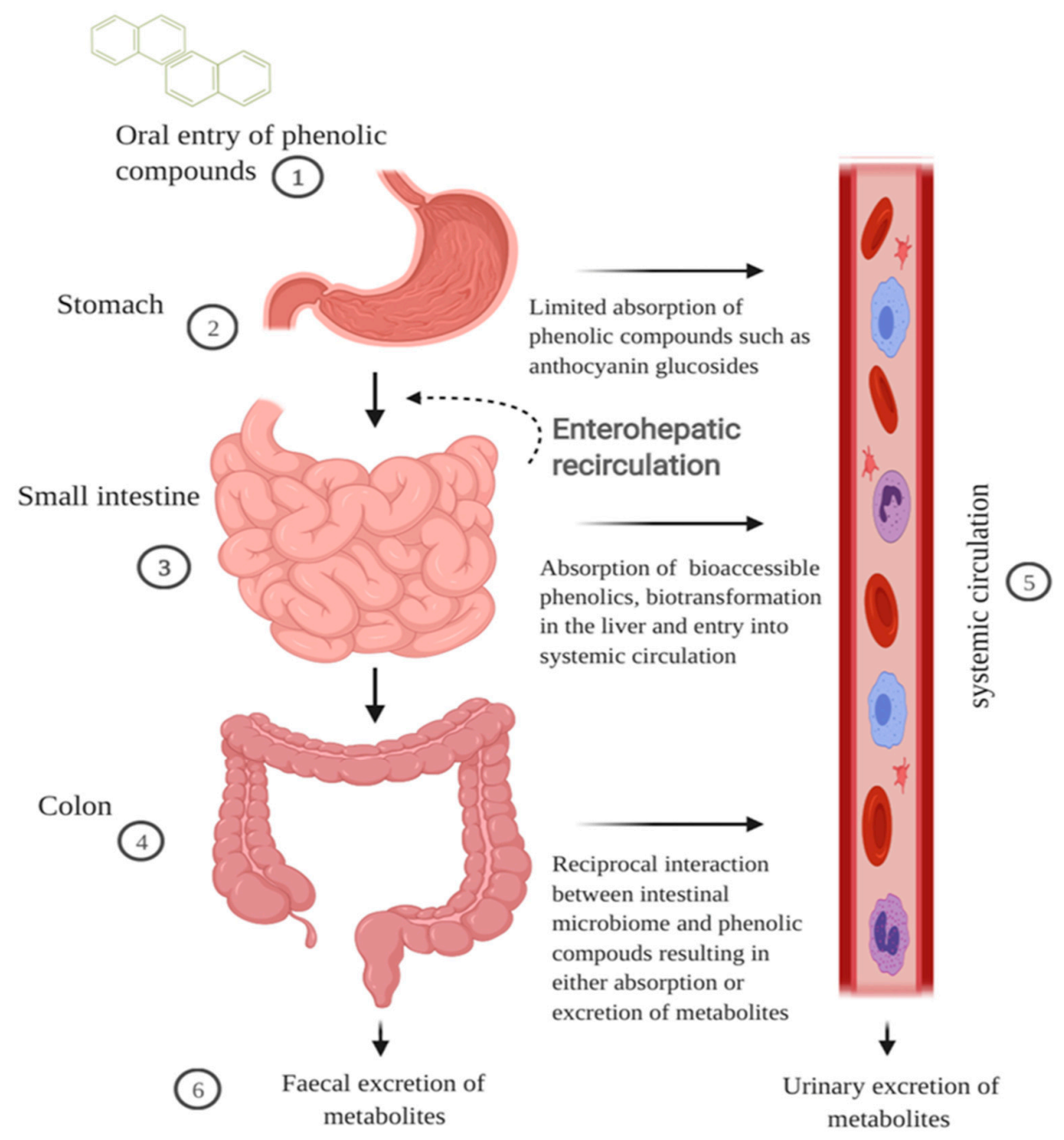

Figure 1. Schematic illustration of the impact of GI digestion in modulating bioavailability of cereal polyphenols. Cereal polyphenols travel through the digestive tract post-ingestion and the majority accumulate in the gut. (1) The cereal matrix forms a bolus and enhances the solubility of hydrophobic polyphenols. (2) Phenolic compounds such as anthocyanin glycosides can be absorbed quickly at the gastric phase. (3) In the small intestine, low molecular weight phenolic compounds are absorbed through active transport or sodium-dependent glucose transport. The first pass metabolism of polyphenols begins in the enterocytes and liver phenolic metabolites return to the intestines via the bile duct excretion. (4) The majority of polyphenols including polymeric compounds and phenolic acids bound to fibre are metabolised in the colon into smaller molecular weight forms that are bioaccessible. (5) Phenolic metabolites in the plasma are transported either freely or bound to blood proteins such as albumin to exert bioactivity in surrounding cells or tissues. (6) Phenolic metabolites are excreted in faeces or urine via the gut or blood, respectively. The figure was created with BioRender.com.

\subsubsection{Small Intestinal Metabolism and Absorption}

In the small intestines, the digesta from the stomach is neutralised by sodium hydroxide allowing intestinal enzymes to catabolize the food matrix [37]. Pancreatic juices containing bile salts, electrolytes and enzymes including pancreatin, proteases and lipases interact with the digesta. Bile salts allow for the micellization of lipophilic compounds [40]. However, it is postulated that, due to the hydrophilic nature of some glycosylated flavonols and derivatives of hydro-cinnamic acid, they may be readily soluble in the aqueous environment, whereas less soluble phenolic compounds such as flavonoid aglycones or procyanidins are bound to dietary fibre and proteins [35]. The stability of the phenolic compounds has been attributed mainly to the $\mathrm{pH}$, with some phenolic compounds being 
degraded through non-enzymatic oxidisation. Anthocyanins, however, are relatively sensitive to $\mathrm{pH}$ in the intestinal phase. Anthocyanin recovery in the intestinal environment (neutral to basic $\mathrm{pH}$ ) is lower than in a gastric environment (acidic $\mathrm{pH}$ ) [41,42]. The discrepancy in the quantification of anthocyanins is due to the $\mathrm{pH}$-dependent equilibrium of the flavylium cation form to other related structural forms above $\mathrm{pH} 2$ [30]. Despite poor recovery after digestion, studies show that anthocyanins can be efficiently absorbed in jejunum tissue $[43,44]$.

It is unclear what specific transport mechanisms are involved in polyphenol intestinal absorption. For monomeric compounds such as cinnamic acid and ferulic acid, a $\mathrm{Na}+$ dependent transport mechanism has been postulated [45,46]. Flavonoid glycosides on the other hand can be transported in enterocytes by sodium-dependent glucose transporter $[47,48]$. Two enzymes, cytosolic $\beta$-glucosidase (CBG) and lactase phlorizin hydrolase $(\mathrm{LPH})$ play a role in the pathway for de-glycosylation of flavonoids. LPH catalyses the hydrolysis of some glucosides on the brush border of the enterocytes (allowing aglycone form to be absorbed, possibly by diffusion) and CBG hydrolyses glucosides once absorbed into the enterocytes [49]. However, anthocyanins such as cyanidin 3-glucosides (C3G) are not substrates to either CBG or LPH but their absorption may be competitively inhibited by the presence of other flavonoids [30,50]. Nonetheless, the lack of enzymatic degradation of some polyphenols as well as their interaction with other dietary antioxidants in the cereal matrix may allow them to accumulate in the colon and exert bioactive functions therein [51].

\subsubsection{Colonic Metabolism}

Polymeric or oligomeric compounds such as pro-anthocyanidins, due to their high molecular weight, are unlikely to be absorbed in the small intestine, but pass through to the colon [50]. Pro-anthocyanidins are not degraded by the acidic condition of the stomach and consequently, due to their poor absorption in the small intestine, may act as key players in cereal-mediated bioactivity in the colon [52]. In the colon, the microbial enzyme rhamnosidase hydrolyses polyphenols conjugated to a rhamnose sugar moiety to facilitate their absorption [46]. Dietary fibres such as xylose, cellulose, $\beta$-glucans, and arabinoxylans that are bound to polyphenols are substrates of microbial catabolism resulting in the production of short-chain fatty acids and the release of polyphenols for absorption [53]. Ferulic acid, found in the bran and aleurone layer of cereals, is usually bound to arabinoxylans and can be released by hydrolysis of ester linkages [54]. The absorption in the intestines is due to the size or number of sugar moieties such as arabinose and xylose.

\subsubsection{Extended Metabolism and Elimination}

The pathway of metabolism for polyphenols is similar to xenobiotics (substances foreign to the body such as environmental chemicals and drugs) and thus involves extensive metabolism to counteract any potential toxic effects [18]. During the first pass metabolism of polyphenols, three main conjugations occur in the small intestine and the liver-glucuronidation, sulfation and methylation $[55,56]$. It is believed that the bioactivity may be reduced due to alteration in solubility and molecular weight of these biotransformed phenolic compounds. Interestingly, sulphate and glucuronate metabolites of ferulic acid and caffeic acid have been shown to retain their strong bioactivity when compared to their parent compounds [57]. This highlights the possibility of cereal phenolic metabolites to retain strong bioactivity locally in the gut and systemically in plasma.

Following extensive metabolism of polyphenols, the half-life in plasma has been reported to be short [46]. However, it has been suggested that the resulting low plasma concentrations are an underestimation, as some phenolic compounds have an affinity to plasma proteins such as albumin $[46,58]$. This warrants confirmation by investigating polyphenolic binding affinity using improved detection and measurement tools. Examination of urinary and faecal excretion demonstrates that cereal consumption results in lower molecular weight phenolic compounds such as ferulic acid, dihydro-ferulic acid, hippuric 
acid, and hydroxy-hippuric acid $[59,60]$. These phenolic compounds may result from the absorption of compounds from the small intestine via colonic catabolism of polymeric compounds, or release compounds bound to the cereal fibre. The impact of the phenolic compounds on the intestinal environment is particularly important as the compounds metabolised in the liver return to the small intestines via the bile duct in a pathway known as enterohepatic recirculation resulting in more exposure to bio-transformed polyphenols [61]. Further investigation into the impact of this pathway on the biotransformation and bioactivity of polyphenols is warranted.

\section{Polyphenol Bioaccessibility in the GI Tract}

Bioaccessibility can be defined as the quantity of a compound available for absorption after GI digestion whereas bioavailability refers to the extent to which a compound enters the systemic circulation to exert bioactivity. The GI tract plays a key role in modulating the bioaccessibility and subsequent bioavailability of polyphenols in vivo. However, interindividual variation creates challenges in analysing bioaccessibility and, thus, an in vitro GI digestion model provides a more standardised approach in analysis $[62,63]$. The model simulates the phases of GI digestion including the oral, gastric and intestinal phases. To determine the recovery of polyphenols post GI digestion, two common models used are small intestine bioaccessibility large intestine bioaccessibility. The former focuses on the amount and type of polyphenols that are absorbed and transported across the small intestine and other upper GI organs whereas the latter focuses on the polyphenols and metabolites absorbed and transported after microbial metabolism in the colon. With both approaches, dialysis tubes or Caco-2 cell monolayers are used to mimic the absorption or transport across the intestines [62].

Bioaccessibility studies on cereal polyphenols are limited, however, evaluating studies from other polyphenol-rich foods may provide insights into their potential bioaccessibility, and inform on the design of bioaccessibility experiments. In the study by Hilary, et al. [64] researchers investigated the phenolic characterisation and bioaccessibility of three different matrices of date seed (powder, bread and phenolic extract). Results indicated that date seed powder and extract recovered more phenolic compounds than the bread form. This may have been attributed to the stronger binding of phenolic compounds to dietary fibre in the bread form. These findings highlight the influence type of food matrix and processing may have on the bioaccessibility of polyphenols, especially those derived from cereals. Furthermore, it was observed that the phenolic compounds increased as digestion progressed (vanillic acid recorded $91 \%$ and $89 \%$ recovery following digestion of the powder and extract form). This observation agreed with the study by Chandrasekara and Shahidi [65] which demonstrated that total phenolic content increased during in vitro GI digestion of cooked millet grains. The antioxidant activity increased 20 -fold in response to the increased phenolic content after digestion. However, the impact on polyphenol antioxidant potential post digestion may vary depending on the cereal matrix. Pigmented cereals rich in anthocyanins have not been thoroughly investigated but are likely to show significant reductions in their antioxidant activity following GI digestion. This is evidenced in the study by Bouayed, et al. [66] that demonstrated an increase in phenolic acids and flavonoids but a significant reduction in antioxidant activity after digestion of different apple varieties. These results may be due to poor recovery and loss of free radical scavenging functional groups of some of the polyphenols, especially anthocyanins, after the intestinal digestion phase.

Interestingly, anthocyanins and phenolic acids in purple rice phenolic extracts have been shown to exhibit antioxidant and anti-inflammatory effects in vitro [13]. However, the chemical and enzymatic conditions of GI digestion are likely to significantly impact their bioaccessibility and bioavailability. Similar to the study of Hilary et al. [64], coupling in vitro GI digestion and Caco-2 transport may reveal the predominant cereal phenolic compounds and anthocyanin metabolites that are bioaccessible. Following in vitro GI digestion of date seeds, Hilary et al. [64] demonstrated that, among the polyphenols recovered, phenolic acids were the predominant compounds transported across a Caco-2 
cell monolayer. In comparison, a cross-over dietary intervention trial employing the same three forms of the same date seeds observed significant antioxidant effects in blood in conjunction with an abundant release of polyphenol metabolites including simple phenolic acids in the urine [67]. Together, these studies display the potential of bioaccessibility models to predict in vivo bioavailability of polyphenols. Furthermore, the study by Lila et al. [68] indicated that berry-derived anthocyanins which showed bioaccessibility in vitro were also observed to be bioavailable in vivo using a radiolabelling strategy. This approach will be valuable in evaluating bioavailability and bioactivity of pigmented cereals in the future. However, in the meantime more in vitro studies evaluating cereal polyphenols bioaccessibility are warranted.

One in vitro study employing Zimbabwean wild cereal grains showed that the bioaccessibility of phenolic compounds was higher in the colon than in the small intestines [69]. The cereal grains with higher fibre content displayed lower bioaccessibility levels of polyphenols indicating the ineffectiveness of digestive enzymes in releasing conjugated polyphenols when compared to microbial enzymes (Table 2). Nevertheless, food processing techniques including extrusion, malting, and fermentation treatment can increase the bioaccessibility of phenolic compounds, particularly those with strong bioactive properties such as ferulic acids and AVNs (Table 2) [70,71]. It should be noted that there is a lack of a standardised approach to measuring bioaccessibility and predicting polyphenol bioavailability. Bioaccessibility studies employ a range of models from simple static models involving only chemical and enzymatic biotransformation to dynamic models from The Netherlands Organisation for applied scientific research (TNO). The TNO gastrointestinal model (TIM-1) simulates peristaltic movement and can closely mimic conditions in both the upper and lower intestines [62]. However, the bioaccessibility of polyphenols post-digestion can be reduced significantly, and consequently in vivo bioactivity may be attributed to the metabolites present. Conversely, a study demonstrated that blackberry extract still retained its protective effect against oxidative damage [72]. These findings are likely attributed to the strong antioxidant phenolic compounds C3G and ellagic acid recovered after digestion. Since cereal polyphenols travel to the colon during digestion, it will be of interest to investigate the impact of simulated GI digestion on the bioactive properties of the polyphenols and their potential impact on gut health.

Table 2. Impact of GI digestion on dietary polyphenol bioaccessibility.

\begin{tabular}{|c|c|c|c|c|}
\hline Food Source & Study Design & $\begin{array}{c}\text { Bioaccessibility } \\
\text { Model }\end{array}$ & Findings & Ref. \\
\hline $\begin{array}{c}\text { Four } \\
\text { Luxembourgish } \\
\text { apple varieties }\end{array}$ & In vitro & $\begin{array}{l}\text { Gastric and } \\
\text { intestinal phase } \\
\text { digestion combined } \\
\text { with dialysis to } \\
\text { assess recovery }\end{array}$ & $\begin{array}{l}\text { More phenolic acids and flavonoids are } \\
\text { released during the gastric phase (65\%) with } \\
\text { a further release during intestinal digestion } \\
(<10 \%) \text {. } \\
\text { - Anthocyanins not detected following } \\
\text { intestinal digestion. } \\
\text { - Antioxidant capacity of dialyzable phenolic } \\
\text { acids were } 57 \% \text { and } 46 \% \text { lower than that of } \\
\text { total antioxidants in fresh apples }\end{array}$ & [66] \\
\hline $\begin{array}{c}\text { Grape seed } \\
\text { phenolic extracts }\end{array}$ & In vitro & $\begin{array}{l}\text { Gastric, intestinal } \\
\text { digestion, and } \\
\text { in vitro ileal and } \\
\text { faecal fermentation } \\
\text { combined with a } \\
\text { Caco-2 cell } \\
\text { transport }\end{array}$ & $\begin{array}{l}\text { - Monomeric phenolic compounds were } \\
\text { significantly increased }(p<0.05) \text { after gastric } \\
\text { digestion. } \\
\text { Only microbial metabolites of the } \\
\text { polyphenols were transported. }\end{array}$ & [73] \\
\hline
\end{tabular}


Table 2. Cont

\begin{tabular}{|c|c|c|c|c|}
\hline Food Source & Study Design & $\begin{array}{c}\text { Bioaccessibility } \\
\text { Model }\end{array}$ & Findings & Ref. \\
\hline $\begin{array}{l}\text { Phoenix } \\
\text { dactylifera L. (date) } \\
\text { seeds; Date seed } \\
\text { powder (DSP), } \\
\text { date seed pita } \\
\text { bread (DSB), date } \\
\text { seed extract (DSE) }\end{array}$ & In vitro & $\begin{array}{l}\text { Gastric and } \\
\text { intestinal phase } \\
\text { digestion combined } \\
\text { with Caco-2 cell } \\
\text { transport }\end{array}$ & $\begin{array}{l}\text { Substantial phenolic acid recovery in DSE } \\
\text { and DSP with vanillic acid recording } 91 \% \text { and } \\
89 \% \text { recovery respectively following in vitro } \\
\text { digestion. DSB did not show any vanillic acid } \\
\text { recovery. } \\
\text { Transport of DSE and DSP polyphenols } \\
\text { including protocatechuic acid, } \\
\text { p-hydroxybenzoic acid, caffeoylshikimic acid, } \\
\text { p-coumaric acid, syringic acid hexoside and } \\
\text { diosmin from across the cell monolayer. } \\
\text { Whereas only protocatechuic acid and } \\
\text { p-hydroxybenzoic acid were transported } \\
\text { from DSB. }\end{array}$ & [64] \\
\hline $\begin{array}{l}\text { Zimbabwean } \\
\text { cereal grains }\end{array}$ & In vitro & $\begin{array}{l}\text { Gastric, intestinal } \\
\text { digestion, and } \\
\text { colonic } \\
\text { fermentation } \\
\text { combined with } \\
\text { dialysis }\end{array}$ & 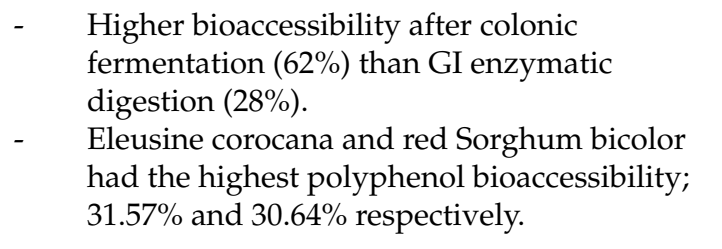 & [69] \\
\hline $\begin{array}{c}\text { Wheat, brown rice, } \\
\text { oat grains }\end{array}$ & In vitro & $\begin{array}{l}\text { Gastric and } \\
\text { intestinal digestion } \\
\text { combined with } \\
\text { dialysis }\end{array}$ & $\begin{array}{l}\text { - The amount of bioaccessibile phenolic } \\
\text { compounds in brown rice, oat and wheat was } \\
528.99,308.83 \text {, and } 443.44 \mu \mathrm{g} \text { FAE/g DW } \\
\text { respectively } \\
\text { After IECT, the total antioxidant activity of } \\
\text { free form polyphenols in brown rice, wheat } \\
\text { and oats was } 63.06 \%, 36.55 \%, 14.39 \% \\
\text { respectively. }\end{array}$ & [74] \\
\hline $\begin{array}{l}\text { Cookies from } \\
\text { malted oat flours } \\
\text { (avenanthramides) }\end{array}$ & In vitro & $\begin{array}{l}\text { Single bioreactor } \\
\text { (oral, gastric and } \\
\text { intestinal phases of } \\
\text { digestion) }\end{array}$ & $\begin{array}{l}\text { Inclusion of } 27 \% \text { malted oat flour increased } \\
\text { AVN content up to } 10 \text {-fold. Likewise, } \\
\text { bioaccessibility with a recovery of } 1703 \mu \mathrm{g} \\
\text { AVNs per } 50 \mathrm{~g} \text { of cookies from malted flour } \\
\text { compared to } 135 \mu \mathrm{g} \text { of control cookies (made } \\
\text { from non-malted flour). }\end{array}$ & [71] \\
\hline Wheat bran & In vitro & $\begin{array}{l}\text { TIM-1 (upper GI } \\
\text { digestion) and } \\
\text { TIM-2 (human } \\
\text { colon fermentation) }\end{array}$ & $\begin{array}{l}\text { Wheat bran ferulic acid bioaccessibility } \\
\text { increased from } 1.1 \% \text { to } 5.5 \% \text { with enzymatic } \\
\text { and fermentation treatment }\end{array}$ & [75] \\
\hline $\begin{array}{c}\text { Extruded Barley } \\
\text { and Oats }\end{array}$ & In vivo (pigs) & $\begin{array}{l}\mathrm{N} / \mathrm{A}-\mathrm{blood} \text { and } \\
\text { faecal samples } \\
\text { collected at the start } \\
\text { and during the trial }\end{array}$ & $\begin{array}{l}\text { Extrusion of the barley and oat grains } \\
\text { increased the bioaccessibility of bound } \\
\text { phenolic acid by } 29 \% \text { and } 14 \% \text {. }\end{array}$ & [70] \\
\hline $\begin{array}{l}\text { Whole grain oat } \\
\text { products }\end{array}$ & In vitro & $\begin{array}{l}\text { Gastrointestinal } \\
\text { digestion (oral, } \\
\text { gastric and } \\
\text { intestinal) coupled } \\
\text { with Caco-2 cell } \\
\text { uptake }\end{array}$ & $\begin{array}{l}\text { - Puffed oat cereal had a higher bioaccessibility } \\
\text { of AVN ( } 89 \%) \text { compared with matching wet } \\
\text { cook porridge (19.1\%) from the same flour. } \\
\text { Intestinal uptake for the digesta was low } \\
\text { (between } 0.16 \% \text { and } 2.71 \% \text { ) for all oat } \\
\text { products. }\end{array}$ & [76] \\
\hline
\end{tabular}


Table 2. Cont.

\begin{tabular}{|c|c|c|c|c|c|}
\hline Food Source & Study Design & $\begin{array}{c}\text { Bioaccessibility } \\
\text { Model }\end{array}$ & & Findings & Ref. \\
\hline $\begin{array}{l}\text { Cooked millet } \\
\text { grains (kodo, } \\
\text { finger, proso, } \\
\text { foxtail and pearl) }\end{array}$ & In vitro & $\begin{array}{l}\text { Gastric, intestinal } \\
\text { digestion, and } \\
\text { colonic } \\
\text { fermentation } \\
\text { combined with } \\
\text { dialysis }\end{array}$ & $\begin{array}{l}- \\
- \\
-\end{array}$ & $\begin{array}{l}\text { Total phenolic content ranged from } 10.2 \text { to } \\
26.9 \mu \mathrm{mol} \text { FAE/g DW at the end of the gastric } \\
\text { phase and this was } 2-5 \text { times more than that } \\
\text { released from aqueous extraction. The } \\
\text { completion of GI digestion significantly } \\
\text { increased total phenolic content to a range } \\
\text { from } 12.7 \text { to } 35.4 \mu \text { mol FAE/g DW. After } \\
\text { in vitro colonic fermentation the phenolic } \\
\text { content was } 4.5 \text { to } 17.1 \mu \text { mol FAE/g DW. } \\
\text { The antioxidant activity was significantly } \\
\text { increased after digestion of the millet grains } \\
\text { (more than } 20 \text {-fold increase when measured } \\
\text { using an ABTS radical anion assay). }\end{array}$ & {$[65]$} \\
\hline
\end{tabular}

N/A, Not Applicable; AVN, avenanthramide; IECT, Improved Extrusion Cooking Treatment; TIM, TNO gastrointestinal model; DSE, Date Seed Extract; DSP, Date Seed Powder; DSB, Date Seed Bread; DW, Dry Weight; FAE, Ferulic Acid Equivalent; ABTS, 2, 2'-Azino-Bis-3Ethylbenzothiazoline-6-Sulfonic Acid.

\section{Impact of Polyphenols on Intestinal Barrier Function}

Without any pathological impairment, the intestinal tract, with the aid of immune cells, mucus and intact epithelium, prevents oxidative damage and the penetration of harmful toxins and pro-inflammatory mediators. On the other hand, it allows the selective permeability of essential nutrients from the lumen. The latter is known as intestinal permeability and is dependent on the integrity of the epithelial barrier [77]. Intestinal diseases and metabolic conditions such as type 2 diabetes and obesity have been linked to impairments of the intestinal integrity and consequently the function of the intestinal barrier [77].

Several studies have focused on understanding how individual phenolic compounds and some dietary extracts impact intestinal barrier function, but there is limited information on cereal phenolic extracts [22,78-80]. Intestinal barrier function can be conserved by the alleviation of oxidative stress and inflammation, induction of mucus production and reduction of intestinal permeability. In vitro cell culture models are often used to simulate oxidative stress- and inflammation-induced damage in the intestines through the use of oxidants (such as hydrogen peroxide and oxysterols, cholesterol auto-oxidation products) and pro-inflammatory mediators such as interleukin 1 beta (IL-1 $\beta$ ), tumour necrosis factor- $\alpha$ (TNF- $\alpha$ ) or lipopolysaccharides (LPS), respectively [22,81]. Upon exposure to polyphenols, the protective response of the intestines may include the secretion of mucus (mucin proteins secreted by goblet cells to provide a physical barrier) and reduced intestinal permeability indicated by the expression of tight junction proteins (Figure 2) [80,81]. Tight junction proteins such as occludin, zona occludens and other adhesion complexes seal adjacent cells to regulate permeability and maintain barrier integrity [82]. Their expression and distribution in polarized intestinal cell monolayers are measured as trans-epithelial electrical resistance (TEER) [82]. On a molecular level, the impact of polyphenols on specific signalling pathways in enterocytes can be investigated by measuring the expression or activity of antioxidant enzymes such as glutathione and superoxide dismutase, and antioxidant and anti-inflammatory regulatory genes such as nuclear factor erythroid 2-related factor 2 (NrF2) or nuclear factor kappa-light-chain-enhancer of activated B cells (NF-kB), respectively [83]. 


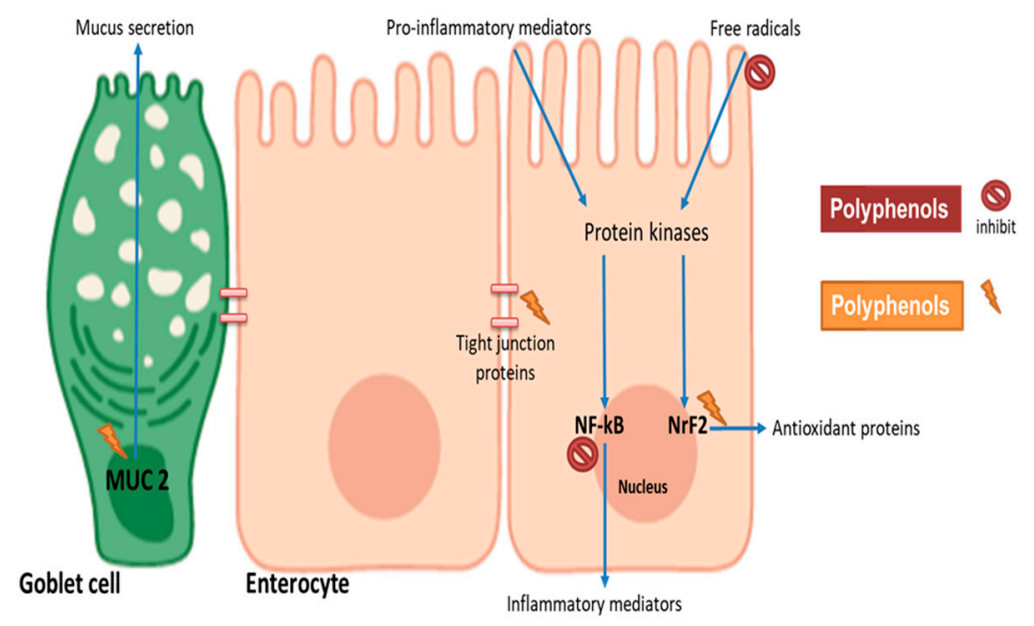

Figure 2. Potential mechanisms involved in polyphenol modulation of intestinal barrier function. Cereal polyphenols may attenuate pro-inflammatory and oxidative stress-induced barrier dysfunction by inhibiting NF-kB and stimulating Nrf2, respectively. Polyphenols may induce the expression of tight junction proteins to enhance barrier integrity. Mucin gene (MUC2) upregulation in goblet cells provides physical layer protection. The figure was created with BioRender.com.

Interestingly, catechins commonly found in tea and some cereals have the potential to impact the signalling pathways in enterocytes. A study employing catechin-rich Fuzhuan brick-tea extract demonstrated that the extract was able to inhibit hydrogen peroxideinduced oxidative damage through the release of antioxidant enzymes and the inhibition of lipid peroxidation in the enterocytes [78]. A recent study showed that catechin-rich green tea could mitigate gliadin-induced inflammation and intestinal permeability [79]. In comparison with the previous study, the catechins attenuated inflammation potentially by complexing with gliadin to prevent the formation of gliadin peptides that mediate intestinal inflammation. Interestingly, pigmented sorghum has been characterised showing catechins to be the most abundant phenolic compound $\left(2.11 \pm 0.47 \mathrm{mg} 100 \mathrm{~g}^{-1}\right.$ gallic acid equivalents in black sorghum) with a relatively high free radical scavenging activity

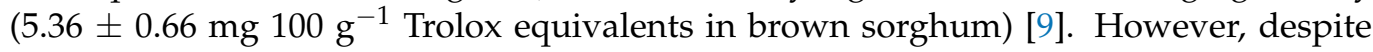
knowledge of their antioxidant potential, there are limited studies of the impact of catechinrich cereals on enterocyte signaling pathways. Moreover, individual phenolic compounds such as epicatechin gallate and quercetin have shown the ability to modulate mucin (MUC2, MUC3, MUC13 and MUC17) expression and secretion from intestinal goblet cells [80]. These bioactive effects were observed at physiologically relevant concentrations, but the underlying mechanisms have not been elucidated.

It is believed that polyphenols interact with multiple aspects of cell signalling to attenuate inflammation and oxidative stress and to induce mucus production [19]. Flavonoids may inhibit the induction of signalling cascade by scavenging free radicals or interfering with the binding of inflammatory mediators to receptors. When absorbed into the enterocytes, the phenolic compounds may interfere with the mitogen-activated protein kinase (MAPK) pathway-a complex array of intracellular signalling cascades involved in cell maturation, cell death and, more importantly, intestinal barrier function. Polyphenols such as catechin may improve barrier function by attenuating the MAPK signalling cascade. This involves the inhibition of c-Jun amino-terminal kinase (JNK), p38 and extracellular signal-regulated kinase (ERK1/2) phosphorylation that occur in NF-kB pro-inflammatory signalling [84]. In addition to MAPK signalling, polyphenols attenuate NF-kB activation by directly inhibiting I kappa B-alpha phosphorylation [85]. On the other hand, in the presence of oxidative stress, phosphorylation of ERK1/2 activates Nrf2 leading to antioxidant protein expression. Polyphenols can activate the Nrf2 gene by enhancing the phosphorylation of ERK1/2, phosphoinositide 3-kinase/Protein kinase B (PI3K/Akt) pathway or inhibiting Keap1 from inactivating Nrf2 through its binding [84]. Interestingly in the presence of 
phenolic compounds, ERK1/2, PI3K/Akt and p38 are activated, thus resulting in the tight junction protein expression to enhance barrier integrity. In the goblet cells, mucin gene expression has been shown to be stimulated by quercetin, enhancing the phosphorylation of ERK1/2, PKC and PLC [86]. Together these studies highlight the fact that polyphenols may improve barrier function by interacting with a common signalling cascade- - the MAPK pathway. However, the modulation of these signalling may differ depending on the type of polyphenols present. A previous study indicating that at $50 \mu \mathrm{M}$ the phenolic compounds chrysin and ellagic inhibited NF-kB activity in intestinal cells, whereas genistein and resveratrol increased it [85]. Thus, it is likely that modulation of MAPK signalling may differ in response to the phenolic composition of different food matrices.

With regards to cereals, there is limited information on the impact of the phenolic extracts on barrier function (Table 3). However, an in vivo study conducted in mice demonstrated that rice bran phenolic extract alleviated endotoxin-induced intestinal barrier dysfunction improving the expression of tight junction proteins [87]. These findings agree with an in vitro study that demonstrated that ferulic acid, a common bioavailable phenolic acid in rice, ameliorates LPS-induced barrier dysfunction by improving tight junction protein expression and activating the PI3K/AKT signalling pathway. Juxtaposed to each other, the studies demonstrate the potential effect of rice polyphenols on barrier integrity. Furthermore, pigmented cereals are rich in phenolic compounds capable of promoting barrier function. Animal studies employing a colitis mice model have demonstrated that supplementation with maize cultivars rich in flavano-4-ols and anthocyanin phenolic compounds reduced gut permeability and proinflammatory cytokine secretion, and enhanced mucus secretion $[21,88]$. The molecular mechanisms involved in the modulation of barrier function, however, need elucidating. Furthermore, since these studies detected changes in the microbiome, it will be interesting to investigate the potential impact of cereal phenolic compounds on the microbiome. 
Table 3. The impact of dietary polyphenols on intestinal barrier function compromised by inflammation and oxidative stress agonists.

\begin{tabular}{|c|c|c|c|c|c|c|c|}
\hline $\begin{array}{c}\text { Polyphenol/Food } \\
\text { Source }\end{array}$ & Significant Dose & Study Design & Agonist & Cell Culture Model & Biomarkers & Findings & Ref. \\
\hline $\begin{array}{l}\text { Cyanidin-3- } \\
\text { glucoside } \\
\text { (C3G) }\end{array}$ & $20 \mu \mathrm{M}$ & In vitro & TNF- $\alpha$ & $\begin{array}{c}\text { Caco-2/HUVEC/ } \\
\text { leucocytes }\end{array}$ & $\begin{array}{l}\text { E-selectin, VCAM-1, } \\
\text { NF-kB and TNF- } \alpha \\
\text { and IL-8 }\end{array}$ & $\begin{array}{l}\text { - } \\
\text { of NF- } \mathrm{kB} \text { and TNF- } \alpha \text { and IL- } 8 \\
\text { gene expression in Caco- } 2 \text { cells. } \\
\text { Inhibition of TNF- } \alpha \text {-stimulated } \\
\text { Caco- } 2 \text { cells endothelial cell } \\
\text { activation as indicated by } \\
\text { increased E-selectin and VCAM-1 } \\
\text { mRNA. }\end{array}$ & [89] \\
\hline $\begin{array}{l}\text { Chlorogenic acid and } \\
\text { epicatechin gallate }\end{array}$ & $10 \mu \mathrm{M}$ & In vitro & $\mathrm{N} / \mathrm{A}$ & $\begin{array}{c}\text { Caco-2 and } \\
\text { HT29-MTX } \\
\text { (mucus-secreting } \\
\text { goblet cells) }\end{array}$ & $\begin{array}{l}\text { Mucin protein and } \\
\text { gene expression }\end{array}$ & $\begin{array}{ll}\text { - } & \text { No significant difference in MUC2 } \\
\text { protein levels post-treatment. } \\
\text { - } \quad \text { Significant downregulation and } \\
\text { upregulation of MUC2 and } \\
\text { MUC17 genes respectively. }\end{array}$ & [80] \\
\hline $\begin{array}{c}\text { Polyphenol-rich } \\
\text { propolis extract (PPE) }\end{array}$ & $50 \mu \mathrm{g} / \mathrm{mL}$ & $\begin{array}{l}\text { In vivo \& in vitro (18 male } \\
\text { Sprague-Dawley rats; } \\
300-320 \mathrm{~g})\end{array}$ & $\mathrm{N} / \mathrm{A}$ & Caco-2 cells & $\begin{array}{l}\text { TEER, LY flux, TJ } \\
\text { proteins (Zonulin } \\
\text { and occludin tight } \\
\text { junction protein gene } \\
\text { expression), AMPK } \\
\text { and ERK expression }\end{array}$ & $\begin{array}{l}\text { - } \quad \text { Increased TEER and decreased } \\
\text { lucifer yellow flux. } \\
\text { - } \quad \text { Increased expression of the tight } \\
\text { junction (TJ) loci occludin and } \\
\text { zona occludens (ZO)-1. } \\
\text { AMPK, ERK1/2, p38, and Akt } \\
\text { signalling was activated in } \\
\text { response to PPE. }\end{array}$ & [20] \\
\hline
\end{tabular}


Table 3. Cont.

\begin{tabular}{|c|c|c|c|c|c|c|c|}
\hline $\begin{array}{l}\text { Polyphenol/Food } \\
\text { Source }\end{array}$ & Significant Dose & Study Design & Agonist & $\begin{array}{l}\text { Cell Culture } \\
\text { Model }\end{array}$ & Biomarkers & Findings & Ref. \\
\hline $\begin{array}{l}\text { Sardinian wine } \\
\text { extracts (red } \\
\text { Cannonau and white } \\
\text { Vermentino) }\end{array}$ & $25 \mu \mathrm{g} / \mathrm{mL}$ & In vitro & Oxysterol & Caco-2 cells & NOX1, IL6 and IL-8 & $\begin{array}{l}\text { - Red Cannonau wine attenuated IL- } 6 \\
\text { and IL- } 8 \text { expression but white } \\
\text { Vermentino wine did not. } \\
\text { The activation of NOX1 prevented by } \\
\text { both extracts. }\end{array}$ & [22] \\
\hline $\begin{array}{l}\text { Green tea } \\
\text { polyphenols }\end{array}$ & $1 \mathrm{mg} / \mathrm{mL}$ & In vitro & Gliadin & Caco-2 cells & $\begin{array}{l}\text { Intestinal } \\
\text { permeability, IL-6 } \\
\text { and IL-8 }\end{array}$ & $\begin{array}{l}\text { - Reduction in gliadin-stimulated } \\
\text { monolayer permeability and IL-6 and } \\
\text { IL-8 release. }\end{array}$ & [79] \\
\hline $\begin{array}{l}\text { Flavan-4-ols- and } \\
\text { anthocyanin- } \\
\text { enriched maize }\end{array}$ & $25 \%(w / w)$ & In vivo (C57BL6 mice) & $\begin{array}{l}\text { Dextran sulfate } \\
\text { sodium (DSS) }\end{array}$ & $\mathrm{N} / \mathrm{A}$ & $\begin{array}{l}\text { Intestinal } \\
\text { permeability, IL-1 } \beta \\
\text { and IL-6 }\end{array}$ & $\begin{array}{l}\text { Attenuation of DSS-induced colitis by } \\
\text { reducing intestinal permeability and } \\
\text { proinflammatory secretion. }\end{array}$ & [21] \\
\hline $\begin{array}{l}\text { Rice bran phenolic } \\
\text { extract (RBPE) }\end{array}$ & $\begin{array}{c}100 \text { and } \\
200 \mathrm{mg} / \mathrm{kg}\end{array}$ & In vivo (C57BL6 mice) & Ethanol & $\mathrm{N} / \mathrm{A}$ & $\begin{array}{l}\text { TJ proteins (ZO- } 1 \text {, } \\
\text { Claudin), TNF- } \alpha \text {, } \\
\text { IL-1 } \beta, \text { IL- } 6, \text { IFN- } \gamma \text {, } \\
\text { and MCP-1 }\end{array}$ & $\begin{array}{l}\text { Increased TJ protein expression and } \\
\text { reduced serum proinflammatory } \\
\text { mediators. }\end{array}$ & [87] \\
\hline
\end{tabular}

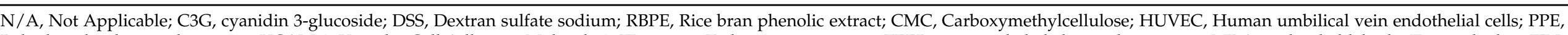

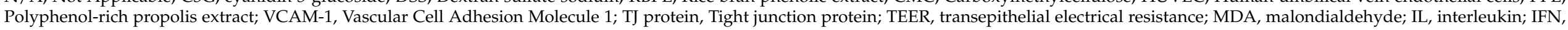

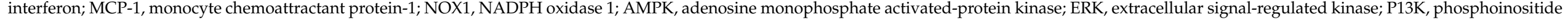
3-kinases; AKT, Protein kinase B; ZO-1, Zonula occludens-1; LY flux, Lucifer yellow flux; GSH, Glutathione; LPS, Liposaccharide; NF-kB, nuclear factor kappa-light-chain-enhancer of activated B cells. 


\section{Cereal Polyphenol Impact on the Gut Microbiome and Plasma Anti-Inflammatory Status}

Gut microbiota is a regulator of intestinal and systemic health that is gaining much attention due to its multifaceted role in modulating host immune response and metabolism [91,92]. Within the GI tract, an abundant and diverse microbial community (more than 300 trillion microbes) exists, with the colon being the most densely populated region [93]. Taxonomically, phyla present in the colon include Firmicutes, Bacteroidetes, Actinobacteria, Proteobacteria, Fusobacteria, and Verrucomicrobia, with Bacteriodetes and Firmicutes being the most abundant phyla $[94,95]$. These bacterial communities maintain intestinal barrier integrity by detoxifying xenobiotics, competing with pathogenic bacteria and keeping the mucosal immune system active $[96,97]$. With the consumption of cereals, the microbiota is predominantly involved in the fermentation of fibre to short-chain fatty acids (SCFAs) such as propionate, butyrate and acetate which in turn serve as an energy source for colonocytes and exert health-promoting effects on the intestinal epithelium [96]. The composition of the microbiome can be altered by factors including age, delivery pattern, drugs and diet [98]. Obesity induced by high-fat diet can lead to dysbiosis wherein there is an increase in the Firmicutes to Bacteriodetes ratio [99]. Metformin, a drug that regulates systemic metabolism by reducing blood glucose, has been shown to alter the gut microbiota composition, thereby suggesting the gut microbiome as a possible signalling pathway for the drug to exerts its physiological functions [100].

There is growing interest in understanding polyphenol interactions with gut microbiota as a key link to explain the health benefits observed in metabolic diseases [95]. Polyphenols are believed to demonstrate a reciprocal relationship with the gut microbiomewhere on the one hand polyphenols are broken down into more bioactive metabolites, and on the other, there is a change in microbiome composition (prebiotic effect) all leading to favourable systemic effects [94,95]. In vitro fermentation studies and dietary intervention, trials have shown that whole grains, when compared to refined grains, enhance the growth of health-promoting bacteria such as Akkermansia, Bifidobacterium and Lactobacillus [94,95]. However, the mechanisms behind the interaction between whole-grain polyphenols and the microbiota in these studies are not well defined. There is some evidence that it is the bran constituents and not the polyphenols alone that alter the microbiota. Kristek, et al. [101] using an in vitro fermentation model of the gut microbiota showed that the whole oat bran, rather than its main bioactive polyphenols, induced an increase in Bifidobacterium and short-chain fatty acids. However, Wang et al. [34] demonstrated that the AVN C in oats are bio-transformed into metabolites such as caffeic acid, 5-hydroxyanthranilic and ferulic acid possibly through the cleavage of $\mathrm{C}^{\prime}-\mathrm{C} 8^{\prime}$ double bond and the cleavage of its amide bond (Table 1). These metabolites coupled with the parent compound AVN were shown in the study to induce apoptosis in colon cancer cells thus potentially promoting gut health. This presents an interesting area of research into clarifying mechanisms by which oat bran polyphenols mediate systemic effects by interacting with the gut microbiome in vivo. Moreover, other phenolic-rich cereal brans have exhibited favourable prebiotic effects.

An in vitro fermentation by Pham, et al. [102] demonstrated that red rice bran polyphenols increased the relative abundance of Faecalibacterium - beneficial bacteria producing butyrate. In the study, however, combined supplementation of ferulyated arabinoxylan oligosaccharides and rice bran phenolic extracts exerted a stronger prebiotic effect-that is, an increased abundance of butyrogenic bacteria, namely Coproccus and Roseburi. A similar synergistic effect was observed within the in vitro fermentation study of Ashley et al. [40]. Results demonstrated that Sumac and Black sorghum bran polyphenols independently stimulated the growth of Roseburia and Prevotella but worked together with a prebiotic, fructo-oligosaccharide to promote the growth of Bifidobacterium and Lactobacillus. Comparing the two studies, it is interesting to note that both sorghum and rice bran phenolic extracts are rich in pro-anthocyanidins. Pro-anthocyanidins have previously been reported to enhance the growth of beneficial bacteria such as Bifidobacteria and Lactobacillus and could 
play a key role in the prebiotic effects observed in cereal brans [103,104]. Furthermore, proanthocyanidins are converted by the gut microbiota into lower molecular weight phenolic acids which may have bioactive relevance in vivo [105]. However, the aforementioned batch fermentation studies did not focus on the phenolic metabolites produced, and thus it may be of interest to investigate the reciprocal interaction between pro-anthocyanidin-rich cereal and the gut microbiome. Moreover, although in vitro batch fermentation models offer a cost-effective approach to study interactions with the microbiome, they are a poor simulation of an in vivo state.

Human dietary intervention trials have been employed to investigate the reciprocal interaction of cereal polyphenols and the microbiome. Some trials have indicated a reduction in systemic inflammation but no significant change on gut microbiota when consuming whole grains as opposed to refined grains $[61,99,106]$. However, in these studies, the phenolic metabolites were not profiled in either plasma or excreta, thus making it difficult to ascertain potential mechanisms for polyphenol interactions with the microbiota. The choice of overweight and obese participants in intervention trials is appropriate as obesity is a chronic subclinical inflammation state associated with gut microbiome dysbiosis and metabolic syndrome risk factors such as dyslipidaemia and hyperglycaemia [95]. Interestingly, studies by Roager, et al. [107] and Kopf, et al. [108] demonstrated that after obese and overweight participants consumed whole grain there was a significant reduction in serum inflammatory markers but no significant change in the gut microbiome. In contrast, Vanegas, et al. [109] and Vitaglione et al. [60] observed a beneficial impact on the gut microbiome, wherein whole grain consumption significantly increased beneficial bacteria (Bacteroides and Lactobacillus) and decreased inflammatory bacteria Enterobacteriaceae. The inconsistent observations on gut microbiome in these studies may be due to other confounding factors such as inter-individual variations in participant race, age and gender. However, Vitaglione et al. [60] measured plasma phenolic metabolites to evaluate microbial metabolism of cereal polyphenols. Results indicated significant increases in serum phenolic metabolites after whole grain consumption which was associated with a significant reduction in TNF- $\alpha$ and IL-10. Reduction in TNF- $\alpha$ levels correlated with increased abundance of beneficial bacteria, thus highlighting a plausible association between microbiome modulation and plasma inflammatory status that needs further investigation. Nevertheless, when comparing the consumption of cereal grains with different phenolic profiles, there is evidence of varying impact on plasma inflammatory status.

Pigmented whole grain varieties have shown significant anti-inflammatory effects that can be attributed to their anthocyanin content. The study by Gamel, et al. [110] showed a significant decrease in TNF- $\alpha$ and an increase in glutathione (GSH), a marker antioxidant status in plasma after consumption of purple wheat. However, only modest differences were observed between the inflammatory status of participants consuming purple wheat and regular wheat. The lack of a strong difference between test groups may be because the total phenolic content of the grains did not vary significantly. Nevertheless, C3G-rich black rice has demonstrated therapeutic benefits by reducing $C$ reactive protein $(C R P)$ in coronary heart disease patients when consumed long term [111]. Purple rice and red rice have also demonstrated anti-inflammatory effects (reduction in IL-6, IL-10 and IL-12) and reduction in lipid peroxidation when consumed acutely in an obese cohort (Table 4) [13]. Anthocyanins in the purple cereals may contribute significantly to the plasma effects seen, but due to their low bioavailability, their respective metabolites in plasma may be the key bioactive players. Thus, further investigation is needed to identify phenolic metabolites produced after GI digestion and breakdown and their correlation with inflammatory changes observed. 
Table 4. Impact of cereal grain polyphenols on gut microbiome composition and inflammation.

\begin{tabular}{|c|c|c|c|c|c|c|c|c|}
\hline $\begin{array}{c}\text { Polyphenol } \\
\text { Rich-Cereal(s) }\end{array}$ & Dose & Population & Study Design & Duration & Gut Microbiome & $\begin{array}{c}\text { Microbial } \\
\text { Metabolites }\end{array}$ & $\begin{array}{l}\text { Inflammatory } \\
\text { Markers }\end{array}$ & Ref. \\
\hline $\begin{array}{l}\text { Oat bran and matched } \\
\text { concentrations of } \\
\beta \text {-glucan extract or } \\
\text { polyphenol mix }\end{array}$ & 1 and $3 \% w / v$ & 3 female donors & $\begin{array}{l}\text { In vitro batch } \\
\text { fermentation }\end{array}$ & $24 \mathrm{~h}$ & $\begin{array}{c}\text { Increases in } \\
\text { Bifidobacterium, and } \\
\text { bacteria from the } \\
\text { phyla of } \\
\text { Proteobacteria and } \\
\text { Bacteriodetes. }\end{array}$ & Increase in SCFA. & $\mathrm{N} / \mathrm{A}$ & [101] \\
\hline $\begin{array}{l}\text { Black sorghum bran } \\
\text { extract, sumac sorghum } \\
\text { bran extract, } \\
\text { fructooligosaccharides } \\
\text { (FOS) }\end{array}$ & $5 \mathrm{~g} / \mathrm{L}$ & $\begin{array}{l}11 \text { each of Obese } \\
\text { and Healthy } \\
\text { weight }\end{array}$ & $\begin{array}{l}\text { In vitro batch } \\
\text { fermentation }\end{array}$ & $24 \mathrm{~h}$ & $\begin{array}{l}\text { Sorghum bran } \\
\text { polyphenols worked } \\
\text { with FOS to enhance } \\
\text { Bifidobacterium and } \\
\text { Lactobacillus, and } \\
\text { independently } \\
\text { stimulated Roseburia } \\
\text { and Prevotella. }\end{array}$ & $\begin{array}{c}\text { No significant } \\
\text { differences in total } \\
\text { and individual SCFA } \\
\text { production were } \\
\text { observed between } \\
\text { obese and healthy } \\
\text { weight subjects. }\end{array}$ & $\mathrm{N} / \mathrm{A}$ & {$[40]$} \\
\hline $\begin{array}{l}\text { Soluble feruloylated } \\
\text { arabinoxylan } \\
\text { oligosaccharides, rice } \\
\text { bran polyphenols }\end{array}$ & $50 \mathrm{mg}$ & $\begin{array}{l}15 \text { males and } \\
17 \text { females } \\
\text { (21-45 years } \\
\text { of age) }\end{array}$ & $\begin{array}{l}\text { In vitro batch } \\
\text { fermentation }\end{array}$ & $24 \mathrm{~h}$ & $\begin{array}{l}\text { Increased butyrogenic } \\
\text { bacteria, Coprococcus } \\
\text { and Roseburia. }\end{array}$ & $\begin{array}{c}\text { No significant } \\
\text { increase in SCFA. }\end{array}$ & $\mathrm{N} / \mathrm{A}$ & [102] \\
\hline $\begin{array}{l}\text { Whole grain (WG) vs. } \\
\text { refined grain (RG) foods }\end{array}$ & $\begin{array}{c}8 \mathrm{~g}(\mathrm{RG}) 16 \mathrm{~g}(\mathrm{WG}) \\
\text { per day }\end{array}$ & $\begin{array}{l}49 \text { men, } 32 \text { women } \\
\text { (ages } 40-65 \text { years) }\end{array}$ & $\begin{array}{l}\text { Randomised, } \\
\text { controlled, } \\
\text { parallel-design } \\
\text { human trial }\end{array}$ & $\begin{array}{l}6 \text { weeks (after } \\
2 \text { weeks run-in } \\
\text { Western-style } \\
\text { diet) }\end{array}$ & $\begin{array}{c}\text { WG group also } \\
\text { showed more increase } \\
\text { in stool weight, stool } \\
\text { frequency and SCFA } \\
\text { bacteria (Lachnospira) } \\
\text { but decreased } \\
\text { proinflammatory } \\
\text { bacteria } \\
\text { (Enterobacteriaceae). }\end{array}$ & $\mathrm{N} / \mathrm{A}$ & $\begin{array}{l}\text { No effect on salivary } \\
\text { IgA concentration or } \\
\text { stool IgA or stool } \\
\text { cytokines } \\
\text { concentrations. A } \\
\text { higher percentage of } \\
\text { terminal effector } \\
\text { memory T cells and } \\
\text { LPS-stimulated ex } \\
\text { vivo production of } \\
\text { TNF- } \alpha \text { in WG than RG } \\
(p=0.004) .\end{array}$ & [109] \\
\hline
\end{tabular}


Table 4. Cont.

\begin{tabular}{|c|c|c|c|c|c|c|c|c|}
\hline $\begin{array}{c}\text { Polyphenol } \\
\text { Rich-Cereal(s) }\end{array}$ & Dose & Population & Study Design & Duration & Gut Microbiome & $\begin{array}{c}\text { Microbial } \\
\text { Metabolites }\end{array}$ & Inflammatory Markers & Ref. \\
\hline $\begin{array}{l}\text { Whole Grain Wheat } \\
\text { (Whole vs. Refined) }\end{array}$ & $\begin{array}{c}70 \mathrm{~g}(\mathrm{WG}) \text { and } \\
60 \mathrm{~g}(\mathrm{RW}) \text { per day }\end{array}$ & $\begin{array}{c}80 \text { healthy } \\
\text { overweight/obese } \\
\text { subjects }\end{array}$ & $\begin{array}{l}\text { A placebo- } \\
\text { controlled, } \\
\text { parallel-group } \\
\text { randomised trial }\end{array}$ & $\begin{array}{l}8 \text { weeks with } \\
\text { measurements } \\
\text { taken at baseline } \\
\text { and every } \\
4 \text { weeks. }\end{array}$ & $\begin{array}{l}\text { TNF- } \alpha \text { reduction with } \\
\text { WG consumption } \\
\text { correlated with } \\
\text { increased abundance } \\
\text { of Bacteroides and } \\
\text { Lactobacillus increases. }\end{array}$ & $\begin{array}{l}\text { WG consumption } \\
\text { increased serum } \\
\text { dihydroferulic acid } \\
\text { and faecal ferulic acid. }\end{array}$ & $\begin{array}{l}\text { TNF- } \alpha \text { and IL-10 } \\
\text { reduced significantly }\end{array}$ & {$[60]$} \\
\hline $\begin{array}{l}\text { Whole grain }(\mathrm{WG}) \\
\text { versus Fruits and } \\
\text { vegetables }(\mathrm{FV})\end{array}$ & 3 servings/day & 49 obese subjects & $\begin{array}{c}\text { Randomised } \\
\text { parallel-arm trial }\end{array}$ & 6 weeks & $\begin{array}{c}\text { No significant } \\
\text { microbiota changes } \\
\text { between groups were } \\
\text { detected. }\end{array}$ & $\mathrm{N} / \mathrm{A}$ & $\begin{array}{l}\text { There was a significant } \\
\text { decrease in LBP for } \\
\text { participants on WG and } \\
\text { FV diets with no change } \\
\text { on the control diet. FV } \\
\text { diet-induced significant } \\
\text { change in IL-6 but no } \\
\text { significant change in the } \\
\text { other diets. WG diet } \\
\text { resulted in a significant } \\
\text { decrease in TNF- } \alpha \\
\text { whereas no significant } \\
\text { effects by the other } \\
\text { diets. }\end{array}$ & [108] \\
\hline WG and RG & $\begin{array}{c}179 \mathrm{~g} / \text { day }(\mathrm{WG}) \\
\text { and } 13 \mathrm{~g} / \text { day (RG) }\end{array}$ & $\begin{array}{c}60 \text { Danish } \\
(20-65 \text { year old } \\
\text { with BMI } \\
\left.25-35 \mathrm{~kg} / \mathrm{m}^{2}\right)\end{array}$ & $\begin{array}{l}\text { A randomised, } \\
\text { controlled } \\
\text { crossover }\end{array}$ & $\begin{array}{l}\text { Two 8-week } \\
\text { intervention }\end{array}$ & $\begin{array}{l}\text { Compared to RG, WG } \\
\text { did not significantly } \\
\text { induce major changes } \\
\text { in faecal microbiome. }\end{array}$ & $\begin{array}{c}\text { Plasma SCFA was not } \\
\text { affected. }\end{array}$ & $\begin{array}{c}\text { WG diet decreased } \\
\text { bodyweight, serum } \\
\text { inflammatory markers, } \\
\text { IL-6 and CRP. }\end{array}$ & [107] \\
\hline $\begin{array}{l}\text { Purple wheat (PW) } \\
\text { and regular wheat } \\
\text { (RW) }\end{array}$ & $\begin{array}{l}4 \text { servings/day } \\
(160 \mathrm{~g} \text { total })\end{array}$ & $\begin{array}{l}29 \text { overweight and } \\
\text { obese subjects }\end{array}$ & $\begin{array}{c}\text { Randomised } \\
\text { Single-blind } \\
\text { parallel-arm study }\end{array}$ & 8 weeks & $\mathrm{N} / \mathrm{A}$ & $\begin{array}{c}\text { No anthocyanins } \\
\text { detected after } 4 \text { and } \\
8 \text { weeks. Ferulic acid } \\
\text { and hippuric acid } \\
\text { detected. No } \\
\text { difference between } \\
\text { PW and RW groups in } \\
\text { terms of total } \\
\text { phenolic acids. }\end{array}$ & $\begin{array}{l}\text { IL-6 and adiponectin } \\
\text { were reduced } \\
\text { significantly with PW. } \\
\text { TNF- } \alpha \text { reduced in both } \\
\text { groups. Plasma GSH } \\
\text { level increased } \\
\text { significantly in } \\
\text { pooled data. }\end{array}$ & [110] \\
\hline
\end{tabular}


Table 4. Cont.

\begin{tabular}{|c|c|c|c|c|c|c|c|c|}
\hline $\begin{array}{l}\text { Polyphenol } \\
\text { Rich-Cereal(s) }\end{array}$ & Dose & Population & Study Design & Duration & Gut Microbiome & $\begin{array}{c}\text { Microbial } \\
\text { Metabolites }\end{array}$ & $\begin{array}{l}\text { Inflammatory } \\
\text { Markers }\end{array}$ & Ref. \\
\hline $\begin{array}{l}\text { Black rice pigmented } \\
\text { fraction (BFR) vs. } \\
\text { white rice pigment } \\
\text { fraction (WRF) }\end{array}$ & $10 \mathrm{~g}$ & $\begin{array}{c}60 \text { Coronary heart } \\
\text { disease patients } \\
(45-75)\end{array}$ & $\begin{array}{l}\text { Randomised } \\
\text { single-blind } \\
\text { parallel-arm }\end{array}$ & 6 months & $\mathrm{N} / \mathrm{A}$ & $\mathrm{N} / \mathrm{A}$ & $\begin{array}{l}\text { No changes in plasma } \\
\text { total superoxide } \\
\text { dismutase activity } \\
\text { and lipid levels. } \\
\text { Reduced levels of } \\
\text { vascular cell adhesion } \\
\text { molecule-1(VCAM-1), } \\
\text { high sensitive } \\
\text { C-reactive protein } \\
\text { (hs-CRP), soluble } \\
\text { CD40 ligand. }\end{array}$ & [111] \\
\hline $\begin{array}{l}\text { Purple rice, red rice } \\
\text { and brown rice }\end{array}$ & 1 serving & $\begin{array}{c}22 \text { obese } \\
\text { participants }\end{array}$ & $\begin{array}{c}\text { Crossover } \\
\text { intervention trial }\end{array}$ & $\begin{array}{l}\text { Over } 4 \mathrm{~h} \text { (30 } \mathrm{min} \text {, } \\
1 \mathrm{~h}, 2 \mathrm{~h} \text { and } 4 \mathrm{~h} \\
\text { time point) }\end{array}$ & $\mathrm{N} / \mathrm{A}$ & $\mathrm{N} / \mathrm{A}$ & $\begin{array}{c}\text { A significant } \\
\text { reduction in MDA } \\
\text { levels with red rice } \\
\text { and purple rice. IL-10 } \\
\text { significantly reduced } \\
\text { with purple rice (30 } \\
\text { min). Red rice } \\
\text { reduced IL-6 at } 30 \text { min } \\
\text { and } 1 \mathrm{~h} \text {. Both purple } \\
\text { and red reduced IL-12 } \\
\text { at } 10 \text { min by } 13.6 \% \\
\text { and } 11.0 \% \\
\text { respectively. Brown } \\
\text { rice did not show any } \\
\text { effects on biomarkers. }\end{array}$ & [13] \\
\hline
\end{tabular}

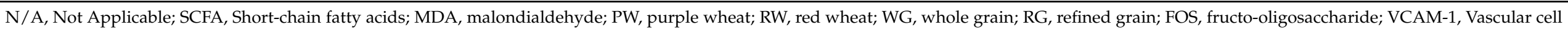
adhesion molecule 1; hs-CRP highly sensitive $\mathrm{C}$ reactive protein; $\mathrm{LBP}$, liposaccharide binding protein; FV, Fruits and vegetables. 


\section{Limitations}

Polyphenols are not the only cereal constituents with health-promoting effects. Fibre, vitamins, and minerals are among the other ingredients that exert beneficial biological effects in vivo. The phenolic profile consisting of the total phenolic content and type of polyphenols within a cereal matrix may result in differential effects between and within cereal genotypes. Furthermore, the allergic potential of gluten-containing cereals also needs consideration as this may nullify the anti-inflammatory effects of phenolic compounds. Further clarification of the polyphenol-gluten interaction within a cereal matrix may lead to the design of less allergenic cereal products. Where allergenicity is not a concern, understanding the interaction between cereal phenolic compounds, the gastrointestinal environment and the intestinal barrier will help to elucidate the molecular signalling pathways underlining the anti-inflammatory and antioxidant responses exerted in vivo. The potential induction of mucin generation is also important and results in a protective barrier for the intestinal epithelium. However, mucin polymers form a barrier between cereal phenolic compounds in the lumen and the intestinal epithelium. Smaller molecular weight phenolic compounds may travel across the mucin marrier to interact with intestinal epithelium. Future studies are warranted to investigate this interaction in vivo. Interestingly, the gut microbiota plays an essential role in modulating specific phenolic compounds that come into contact with the intestinal epithelium. Furthermore, increases in mucin-degrading microbiota such as Akkermansia have been correlated with polyphenol intake in high fat diet-induced obese mice [99]. This highlights the role the interaction between microbiome, mucin and polyphenols can play in maintaining intestinal integrity. Moreover, the relationship between changes in microbiome and inflammation following cereal polyphenol intake needs investigation. The dose and duration of phenolic-rich cereals have to be considered as they may influence the physiological effects observed (Tables 3 and 4). There is likely to be a complex mechanism in action, due to the rapid absorption of free phenolic compounds and the accumulation of fibre bound phenolic compounds in the colon. Phenolic metabolites and short-chain fatty acids from microbial metabolism, once absorbed, may contribute to the overall plasma anti-inflammatory and antioxidant status. However, well-controlled intervention trials will be needed to support this hypothesis.

\section{Conclusions}

Cereal polyphenols have the potential to modulate intestinal health and systemic inflammatory status. Polyphenol bioaccessibility is low but dependent on the type of polyphenol or cereal matrix involved. Phenolic compounds target specific mechanistic pathways involved in maintaining intestinal barrier function. When consumed, cereal polyphenols can potentially change the gut microbiome favourably and, in turn, improve plasma antioxidant and anti-inflammatory status. Nevertheless, there is limited data on the bioaccessibility and bioavailability of cereal polyphenols and their interaction with the intestinal barrier, gut microbiome, and plasma inflammatory mediators. Further studies in these areas may reveal a novel mechanism involved in polyphenol bioactivity and lead to the breeding and selection of polyphenol-rich cereal grains.

Author Contributions: Conceptualization, B.E.N., N.F., C.B. and A.B.S.; Writing-Original Draft Preparation, B.E.N.; Writing-Review and Editing, B.E.N., N.F., C.B. and A.B.S.; Supervision, N.F., C.B. and A.B.S. All authors have read and agreed to the published version of the manuscript.

Funding: This research received no external funding.

Conflicts of Interest: The authors declare no conflict of interest. 


\section{References}

1. McKevith, B. Nutritional aspects of cereals. Nutr. Bull. 2004, 29, 111-142. [CrossRef]

2. Kushi, L.H.; Meyer, K.A.; Jacobs, D.R., Jr. Cereals, legumes, and chronic disease risk reduction: Evidence from epidemiologic studies. Am. J. Clin. Nutr. 1999, 70, 451s-458s. [CrossRef]

3. Stainer, A.R.; Sasikumar, P.; Bye, A.P.; Unsworth, A.J.; Holbrook, L.M.; Tindall, M.; Lovegrove, J.A.; Gibbins, J.M. The Metabolites of the Dietary Flavonoid Quercetin Possess Potent Antithrombotic Activity, and Interact with Aspirin to Enhance Antiplatelet Effects. TH Open 2019, 3, e244-e258. [CrossRef]

4. Francis, N.; Rao, S.; Blanchard, C.; Santhakumar, A. Black Sorghum Phenolic Extract Regulates Expression of Genes Associated with Oxidative Stress and Inflammation in Human Endothelial Cells. Molecules 2019, 24, 3321. [CrossRef]

5. Santhakumar, A.B.; Bulmer, A.C.; Singh, I. A review of the mechanisms and effectiveness of dietary polyphenols in reducing oxidative stress and thrombotic risk. J. Hum. Nutr. Diet. 2014, 27, 1-21. [CrossRef]

6. Thompson, K.; Hosking, H.; Pederick, W.; Singh, I.; Santhakumar, A. The effect of anthocyanin supplementation in modulating platelet function in sedentary population: A randomised, double-blind, placebo-controlled, cross-over trial. Br. J. Nutr. 2017, 118, 368-374. [CrossRef]

7. Santhakumar, A.B.; Battino, M.; Alvarez-Suarez, J.M. Dietary polyphenols: Structures, bioavailability and protective effects against atherosclerosis. Food Chem. Toxicol. Int. J. Publ. Br. Ind. Biol. Res. Assoc. 2018, 113, 49-65. [CrossRef] [PubMed]

8. Lin, C.-Z.; Zhu, C.-C.; Hu, M.; Wu, A.-Z.; Bairu, Z.-D.; Kangsa, S.-Q. Structure-activity relationships of antioxidant activity in vitro about flavonoids isolated from Pyrethrum tatsienense. J. Intercult. Ethnopharmacol. 2014, 3, 123-127. [CrossRef] [PubMed]

9. Rao, S.; Santhakumar, A.B.; Chinkwo, K.A.; Wu, G.; Johnson, S.K.; Blanchard, C.L. Characterization of phenolic compounds and antioxidant activity in sorghum grains. J. Cereal Sci. 2018, 84, 103-111. [CrossRef]

10. Rao, S.; Schwarz, L.J.; Santhakumar, A.B.; Chinkwo, K.A.; Blanchard, C.L. Cereal phenolic contents as affected by variety and environment. Cereal Chem. 2018, 95, 589-602. [CrossRef]

11. Wu, G.; Johnson, S.K.; Bornman, J.F.; Bennett, S.J.; Fang, Z. Changes in whole grain polyphenols and antioxidant activity of six sorghum genotypes under different irrigation treatments. Food Chem. 2017, 214, 199-207. [CrossRef] [PubMed]

12. Yahfoufi, N.; Alsadi, N.; Jambi, M.; Matar, C. The Immunomodulatory and Anti-Inflammatory Role of Polyphenols. Nutrients 2018, 10, 1618. [CrossRef] [PubMed]

13. Callcott, E.T.; Blanchard, C.L.; Snell, P.; Santhakumar, A.B. The anti-inflammatory and antioxidant effects of pigmented rice consumption in an obese cohort. Food Funct. 2019, 10, 8016-8025. [CrossRef] [PubMed]

14. Callcott, E.T.; Santhakumar, A.B.; Strappe, P.; Luo, J.; Blanchard, C.L. Polyphenols from Australian-grown pigmented red and purple rice inhibit adipocyte differentiation. J. Cereal Sci. 2018, 81, 140-146. [CrossRef]

15. Fernandes, I.; de Freitas, V.; Mateus, N. Anthocyanins and human health: How gastric absorption may influence acute human physiology. Nutr. Aging 2014, 2, 1-14. [CrossRef]

16. Talavéra, S.; Felgines, C.; Texier, O.; Besson, C.; Lamaison, J.-L.; Rémésy, C. Anthocyanins Are Efficiently Absorbed from the Stomach in Anesthetized Rats. J. Nutr. 2003, 133, 4178-4182. [CrossRef]

17. Talavéra, S.; Felgines, C.; Texier, O.; Besson, C.; Manach, C.; Lamaison, J.L.; Rémésy, C. Anthocyanins are efficiently absorbed from the small intestine in rats. J. Nutr. 2004, 134, 2275-2279. [CrossRef]

18. D'Archivio, M.; Filesi, C.; Varì, R.; Scazzocchio, B.; Masella, R. Bioavailability of the polyphenols: Status and controversies. Int. J. Mol. Sci. 2010, 11, 1321-1342. [CrossRef]

19. Bianchi, M.G.; Chiu, M.; Taurino, G.; Brighenti, F.; Del Rio, D.; Mena, P.; Bussolati, O. Catechin and Procyanidin B(2) Modulate the Expression of Tight Junction Proteins but Do Not Protect from Inflammation-Induced Changes in Permeability in Human Intestinal Cell Monolayers. Nutrients 2019, 11, 2271. [CrossRef]

20. Wang, K.; Jin, X.; Chen, Y.; Song, Z.; Jiang, X.; Hu, F.; Conlon, M.A.; Topping, D.L. Polyphenol-Rich Propolis Extracts Strengthen Intestinal Barrier Function by Activating AMPK and ERK Signaling. Nutrients 2016, 8, 272. [CrossRef]

21. Wu, B.; Li, S.; Chang, H.; Anderson, R.; Chopra, S.; Reddivari, L. Maize Flavan-4-ols and Anthocyanins Alleviated Dextran Sulfate Sodium-Induced Colitis in Mice via Intestinal Barrier Function Restoration. Curr. Dev. Nutr. 2020, 4, 488. [CrossRef]

22. Biasi, F.; Guina, T.; Maina, M.; Cabboi, B.; Deiana, M.; Tuberoso, C.I.; Calfapietra, S.; Chiarpotto, E.; Sottero, B.; Gamba, P.; et al. Phenolic compounds present in Sardinian wine extracts protect against the production of inflammatory cytokines induced by oxysterols in CaCo-2 human enterocyte-like cells. Biochem. Pharmacol. 2013, 86, 138-145. [CrossRef]

23. Rao, S.; Santhakumar, A.B.; Chinkwo, K.A.; Blanchard, C.L. Characterization of phenolic compound antioxidant activity in oat varieties using UHPLC-online ABTS and LC Q-TOF. Cereal Chem. 2019, 96, 958-966. [CrossRef]

24. Natella, F.; Nardini, M.; Di Felice, M.; Scaccini, C. Benzoic and Cinnamic Acid Derivatives as Antioxidants: Structure-Activity Relation. J. Agric. Food Chem. 1999, 47, 1453-1459. [CrossRef] [PubMed]

25. Simić, A.; Manojlović, D.; Segan, D.; Todorović, M. Electrochemical behavior and antioxidant and prooxidant activity of natural phenolics. Molecules 2007, 12, 2327-2340. [CrossRef] [PubMed]

26. Woong, K.; Beomgi, L.; Jaeyoung, P.; Ho-Joong, K.; Hyeonsook, C. Comparative Antioxidant Activity and Structural Feature of Protocatechuic Acid and Phenolic Acid Derivatives by DPPH and Intracellular ROS. Lett. Drug Des. Discov. 2018, 15, 612-620. [CrossRef]

27. Ganeshpurkar, A.; Saluja, A.K. The Pharmacological Potential of Rutin. Saudi Pharm. J. 2017, 25, 149-164. [CrossRef] [PubMed] 
28. Awika, J.M.; Rose, D.J.; Simsek, S. Complementary effects of cereal and pulse polyphenols and dietary fiber on chronic inflammation and gut health. Food Funct. 2018, 9, 1389-1409. [CrossRef]

29. Kong, J.-M.; Chia, L.-S.; Goh, N.-K.; Chia, T.-F.; Brouillard, R. Analysis and biological activities of anthocyanins. Phytochemistry 2003, 64, 923-933. [CrossRef]

30. Fang, J. Bioavailability of anthocyanins. Drug Metab. Rev. 2014, 46, 508-520. [CrossRef]

31. Bratt, K.; Sunnerheim, K.; Bryngelsson, S.; Fagerlund, A.; Engman, L.; Andersson, R.E.; Dimberg, L.H. Avenanthramides in oats (Avena sativa L.) and structure-antioxidant activity relationships. J. Agric. Food Chem. 2003, 51, 594-600. [CrossRef]

32. Chen, C.Y.; Milbury, P.E.; Collins, F.W.; Blumberg, J.B. Avenanthramides are bioavailable and have antioxidant activity in humans after acute consumption of an enriched mixture from oats. J. Nutr. 2007, 137, 1375-1382. [CrossRef]

33. Peterson, D.M.; Hahn, M.J.; Emmons, C.L. Oat avenanthramides exhibit antioxidant activities in vitro. Food Chem. 2002, 79, 473-478. [CrossRef]

34. Wang, P.; Chen, H.; Zhu, Y.; McBride, J.; Fu, J.; Sang, S. Oat Avenanthramide-C (2c) Is Biotransformed by Mice and the Human Microbiota into Bioactive Metabolites. J. Nutr. 2014, 145, 239-245. [CrossRef] [PubMed]

35. Alminger, M.; Aura, A.-M.; Bohn, T.; Dufour, C.; El, S.N.; Gomes, A.; Karakaya, S.; Martínez-Cuesta, M.C.; McDougall, G.J.; Requena, T.; et al. In Vitro Models for Studying Secondary Plant Metabolite Digestion and Bioaccessibility. Compr. Rev. Food Sci. Food Saf. 2014, 13, 413-436. [CrossRef] [PubMed]

36. Joye, I. Protein Digestibility of Cereal Products. Foods 2019, 8, 199. [CrossRef] [PubMed]

37. Wojtunik-Kulesza, K.; Oniszczuk, A.; Oniszczuk, T.; Combrzyński, M.; Nowakowska, D.; Matwijczuk, A. Influence of In Vitro Digestion on Composition, Bioaccessibility and Antioxidant Activity of Food Polyphenols-A Non-Systematic Review. Nutrients 2020, 12, 1401. [CrossRef]

38. Spencer, J.P.; Chaudry, F.; Pannala, A.S.; Srai, S.K.; Debnam, E.; Rice-Evans, C. Decomposition of cocoa procyanidins in the gastric milieu. Biochem. Biophys. Res. Commun. 2000, 272, 236-241. [CrossRef]

39. Passamonti, S.; Vrhovsek, U.; Mattivi, F. The interaction of anthocyanins with bilitranslocase. Biochem. Biophys. Res. Commun. 2002, 296, 631-636. [CrossRef]

40. Ashley, D.; Marasini, D.; Brownmiller, C.; Lee, J.A.; Carbonero, F.; Lee, S.-O. Impact of Grain Sorghum Polyphenols on Microbiota of Normal Weight and Overweight/Obese Subjects during In Vitro Fecal Fermentation. Nutrients 2019, 11, 217. [CrossRef]

41. McDougall, G.J.; Dobson, P.; Smith, P.; Blake, A.; Stewart, D. Assessing Potential Bioavailability of Raspberry Anthocyanins Using an in Vitro Digestion System. J. Agric. Food Chem. 2005, 53, 5896-5904. [CrossRef] [PubMed]

42. Pérez-Vicente, A.; Gil-Izquierdo, A.; García-Viguera, C. In Vitro Gastrointestinal Digestion Study of Pomegranate Juice Phenolic Compounds, Anthocyanins, and Vitamin C. J. Agric. Food Chem. 2002, 50, 2308-2312. [CrossRef] [PubMed]

43. Cai, H.; Thomasset, S.C.; Berry, D.P.; Garcea, G.; Brown, K.; Steward, W.P.; Gescher, A.J. Determination of anthocyanins in the urine of patients with colorectal liver metastases after administration of bilberry extract. Biomed. Chromatogr. 2011, 25, 660-663. [CrossRef] [PubMed]

44. Talavéra, S.; Felgines, C.; Texier, O.; Besson, C.; Gil-Izquierdo, A.; Lamaison, J.L.; Rémésy, C. Anthocyanin metabolism in rats and their distribution to digestive area, kidney, and brain. J. Agric. Food Chem. 2005, 53, 3902-3908. [CrossRef]

45. Ader, P.; Grenacher, B.; Langguth, P.; Scharrer, E.; Wolffram, S. Cinnamate uptake by rat small intestine: Transport kinetics and transepithelial transfer. Exp. Physiol. 1996, 81, 943-955. [CrossRef]

46. Manach, C.; Williamson, G.; Morand, C.; Scalbert, A.; Rémésy, C. Bioavailability and bioefficacy of polyphenols in humans. I. Review of 97 bioavailability studies. Am. J. Clin. Nutr. 2005, 81, 230S-242S. [CrossRef] [PubMed]

47. Wolffram, S.; Blöck, M.; Ader, P. Quercetin-3-Glucoside Is Transported by the Glucose Carrier SGLT1 across the Brush Border Membrane of Rat Small Intestine. J. Nutr. 2002, 132, 630-635. [CrossRef]

48. Li, S.; Liu, J.; Li, Z.; Wang, L.; Gao, W.; Zhang, Z.; Guo, C. Sodium-dependent glucose transporter 1 and glucose transporter 2 mediate intestinal transport of quercetrin in Caco-2 cells. Food Nutr. Res. 2020, 64. [CrossRef]

49. Day, A.J.; Cañada, F.J.; Díaz, J.C.; Kroon, P.A.; Mclauchlan, R.; Faulds, C.B.; Plumb, G.W.; Morgan, M.R.A.; Williamson, G. Dietary flavonoid and isoflavone glycosides are hydrolysed by the lactase site of lactase phlorizin hydrolase. FEBS Lett. 2000, 468, 166-170. [CrossRef]

50. Walton, M.C.; McGhie, T.K.; Reynolds, G.W.; Hendriks, W.H. The flavonol quercetin-3-glucoside inhibits cyanidin-3-glucoside absorption in vitro. J. Agric. Food Chem. 2006, 54, 4913-4920. [CrossRef]

51. Kamiloglu, S.; Tomas, M.; Ozdal, T.; Capanoglu, E. Effect of food matrix on the content and bioavailability of flavonoids. Trends Food Sci. Technol. 2020. [CrossRef]

52. Rios, L.Y.; Bennett, R.N.; Lazarus, S.A.; Rémésy, C.; Scalbert, A.; Williamson, G. Cocoa procyanidins are stable during gastric transit in humans. Am. J. Clin. Nutr. 2002, 76, 1106-1110. [CrossRef]

53. Călinoiu, L.F.; Vodnar, D.C. Whole Grains and Phenolic Acids: A Review on Bioactivity, Functionality, Health Benefits and Bioavailability. Nutrients 2018, 10, 1615. [CrossRef] [PubMed]

54. Mateo Anson, N.; van den Berg, R.; Havenaar, R.; Bast, A.; Haenen, G.R.M.M. Bioavailability of ferulic acid is determined by its bioaccessibility. J. Cereal Sci. 2009, 49, 296-300. [CrossRef]

55. Boersma, M.G.; van der Woude, H.; Bogaards, J.; Boeren, S.; Vervoort, J.; Cnubben, N.H.; van Iersel, M.L.; van Bladeren, P.J.; Rietjens, I.M. Regioselectivity of phase II metabolism of luteolin and quercetin by UDP-glucuronosyl transferases. Chem. Res. Toxicol. 2002, 15, 662-670. [CrossRef] 
56. Manach, C.; Scalbert, A.; Morand, C.; Rémésy, C.; Jiménez, L. Polyphenols: Food sources and bioavailability. Am. J. Clin. Nutr. 2004, 79, 727-747. [CrossRef] [PubMed]

57. Piazzon, A.; Vrhovsek, U.; Masuero, D.; Mattivi, F.; Mandoj, F.; Nardini, M. Antioxidant Activity of Phenolic Acids and Their Metabolites: Synthesis and Antioxidant Properties of the Sulfate Derivatives of Ferulic and Caffeic Acids and of the Acyl Glucuronide of Ferulic Acid. J. Agric. Food Chem. 2012, 60, 12312-12323. [CrossRef]

58. Cao, H.; Liu, X.; Ulrih, N.P.; Sengupta, P.K.; Xiao, J. Plasma protein binding of dietary polyphenols to human serum albumin: A high performance affinity chromatography approach. Food Chem. 2019, 270, 257-263. [CrossRef]

59. Price, R.K.; Welch, R.W.; Lee-Manion, A.M.; Bradbury, I.; Strain, J.J. Total Phenolics and Antioxidant Potential in Plasma and Urine of Humans after Consumption of Wheat Bran. Cereal Chem. 2008, 85, 152-157. [CrossRef]

60. Vitaglione, P.; Mennella, I.; Ferracane, R.; Rivellese, A.A.; Giacco, R.; Ercolini, D.; Gibbons, S.M.; La Storia, A.; Gilbert, J.A.; Jonnalagadda, S.; et al. Whole-grain wheat consumption reduces inflammation in a randomized controlled trial on overweight and obese subjects with unhealthy dietary and lifestyle behaviors: Role of polyphenols bound to cereal dietary fiber. Am. J. Clin. Nutr. 2015, 101, 251-261. [CrossRef]

61. Anhê, F.F.; Varin, T.V.; Le Barz, M.; Pilon, G.; Dudonné, S.; Trottier, J.; St-Pierre, P.; Harris, C.S.; Lucas, M.; Lemire, M.; et al. Arctic berry extracts target the gut-liver axis to alleviate metabolic endotoxaemia, insulin resistance and hepatic steatosis in diet-induced obese mice. Diabetologia 2018, 61,919-931. [CrossRef]

62. Carbonell-Capella, J.M.; Buniowska, M.; Barba, F.J.; Esteve, M.J.; Frígola, A. Analytical Methods for Determining Bioavailability and Bioaccessibility of Bioactive Compounds from Fruits and Vegetables: A Review. Compr. Rev. Food Sci. Food Saf. 2014, 13, 155-171. [CrossRef] [PubMed]

63. Brodkorb, A.; Egger, L.; Alminger, M.; Alvito, P.; Assunção, R.; Ballance, S.; Bohn, T.; Bourlieu-Lacanal, C.; Boutrou, R.; Carrière, F.; et al. INFOGEST static in vitro simulation of gastrointestinal food digestion. Nat. Protoc. 2019, 14, 991-1014. [CrossRef] [PubMed]

64. Hilary, S.; Tomás-Barberán, F.A.; Martinez-Blazquez, J.A.; Kizhakkayil, J.; Souka, U.; Al-Hammadi, S.; Habib, H.; Ibrahim, W.; Platat, C. Polyphenol characterisation of Phoenix dactylifera L. (date) seeds using HPLC-mass spectrometry and its bioaccessibility using simulated in-vitro digestion/Caco-2 culture model. Food Chem. 2020, 311, 125969. [CrossRef] [PubMed]

65. Chandrasekara, A.; Shahidi, F. Bioaccessibility and antioxidant potential of millet grain phenolics as affected by simulated in vitro digestion and microbial fermentation. J. Funct. Foods 2012, 4, 226-237. [CrossRef]

66. Bouayed, J.; Hoffmann, L.; Bohn, T. Total phenolics, flavonoids, anthocyanins and antioxidant activity following simulated gastro-intestinal digestion and dialysis of apple varieties: Bioaccessibility and potential uptake. Food Chem. 2011, 128, 14-21. [CrossRef] [PubMed]

67. Platat, C.; Hillary, S.; Tomas-Barberan, F.A.; Martinez-Blazquez, J.A.; Al-Meqbali, F.; Souka, U.; Al-Hammadi, S.; Ibrahim, W. Urine Metabolites and Antioxidant Effect after Oral Intake of Date (Phoenix dactylifera L.) Seeds-Based Products (Powder, Bread and Extract) by Human. Nutrients 2019, 11, 2489. [CrossRef]

68. Lila, M.A.; Ribnicky, D.M.; Rojo, L.E.; Rojas-Silva, P.; Oren, A.; Havenaar, R.; Janle, E.M.; Raskin, I.; Yousef, G.G.; Grace, M.H. Complementary Approaches To Gauge the Bioavailability and Distribution of Ingested Berry Polyphenolics. J. Agric. Food Chem. 2012, 60, 5763-5771. [CrossRef]

69. Chitindingu, K.; Benhura, M.A.N.; Muchuweti, M. In vitro bioaccessibility assessment of phenolic compounds from selected cereal grains: A prediction tool of nutritional efficiency. LWT Food Sci. Technol. 2015, 63, 575-581. [CrossRef]

70. Hole, A.S.; Kjos, N.P.; Grimmer, S.; Kohler, A.; Lea, P.; Rasmussen, B.; Lima, L.R.; Narvhus, J.; Sahlstrøm, S. Extrusion of Barley and Oat Improves the Bioaccessibility of Dietary Phenolic Acids in Growing Pigs. J. Agric. Food Chem. 2013, 61, $2739-2747$. [CrossRef]

71. Ninfali, P.; Mari, M.; Meli, M.A.; Roselli, C.; Antonini, E. In vitro bioaccessibility of avenanthramides in cookies made with malted oat flours. Int. J. Food Sci. Technol. 2019, 54, 1558-1565. [CrossRef]

72. Chen, W.; Su, H.; Xu, Y.; Jin, C. In vitro gastrointestinal digestion promotes the protective effect of blackberry extract against acrylamide-induced oxidative stress. Sci. Rep. 2017, 7, 40514. [CrossRef]

73. Wang, D.; Williams, B.A.; Ferruzzi, M.G.; D'Arcy, B.R. Microbial metabolites, but not other phenolics derived from grape seed phenolic extract, are transported through differentiated Caco-2 cell monolayers. Food Chem. 2013, 138, 1564-1573. [CrossRef] [PubMed]

74. Zeng, Z.; Liu, C.; Luo, S.; Chen, J.; Gong, E. The Profile and Bioaccessibility of Phenolic Compounds in Cereals Influenced by Improved Extrusion Cooking Treatment. PLoS ONE 2016, 11, e0161086. [CrossRef] [PubMed]

75. Anson, N.M.; Selinheimo, E.; Havenaar, R.; Aura, A.M.; Mattila, I.; Lehtinen, P.; Bast, A.; Poutanen, K.; Haenen, G.R. Bioprocessing of wheat bran improves in vitro bioaccessibility and colonic metabolism of phenolic compounds. J. Agric. Food Chem. 2009, 57, 6148-6155. [CrossRef]

76. Li, M.; Koecher, K.; Hansen, L.; Ferruzzi, M.G. Phenolic recovery and bioaccessibility from milled and finished whole grain oat products. Food Funct. 2016, 7, 3370-3381. [CrossRef]

77. Tran, C.D.; Grice, D.M.; Wade, B.; Kerr, C.A.; Bauer, D.C.; Li, D.; Hannan, G.N. Gut permeability, its interaction with gut microflora and effects on metabolic health are mediated by the lymphatics system, liver and bile acid. Future Microbiol. 2015, 10, 1339-1353. [CrossRef] [PubMed]

78. Song, J.L.; Gao, Y. Effects of methanolic extract form Fuzhuan brick-tea on hydrogen peroxide-induced oxidative stress in human intestinal epithelial adenocarcinoma Caco-2 cells. Mol. Med. Rep. 2014, 9, 1061-1067. [CrossRef] 
79. Van Buiten, C.B.; Lambert, J.D.; Elias, R.J. Green Tea Polyphenols Mitigate Gliadin-Mediated Inflammation and Permeability in Vitro. Mol. Nutr. Food Res. 2018, 62, e1700879. [CrossRef]

80. Volstatova, T.; Marchica, A.; Hroncova, Z.; Bernardi, R.; Doskocil, I.; Havlik, J. Effects of chlorogenic acid, epicatechin gallate, and quercetin on mucin expression and secretion in the Caco-2/HT29-MTX cell model. Food Sci. Nutr. 2019, 7, 492-498. [CrossRef]

81. Valdez, J.C.; Cho, J.; Bolling, B.W. Aronia berry inhibits disruption of Caco-2 intestinal barrier function. Arch. Biochem. Biophys. 2020, 688, 108409. [CrossRef] [PubMed]

82. Srinivasan, B.; Kolli, A.R.; Esch, M.B.; Abaci, H.E.; Shuler, M.L.; Hickman, J.J. TEER measurement techniques for in vitro barrier model systems. J. Lab. Autom. 2015, 20, 107-126. [CrossRef]

83. Kaulmann, A.; Bohn, T. Bioactivity of Polyphenols: Preventive and Adjuvant Strategies toward Reducing Inflammatory Bowel Diseases-Promises, Perspectives, and Pitfalls. Oxidative Med. Cell. Longev. 2016, 2016, 9346470. [CrossRef] [PubMed]

84. Fan, F.-Y.; Sang, L.-X.; Jiang, M. Catechins and Their Therapeutic Benefits to Inflammatory Bowel Disease. Molecules 2017, $22,484$. [CrossRef]

85. Romier, B.; Van De Walle, J.; During, A.; Larondelle, Y.; Schneider, Y.J. Modulation of signalling nuclear factor-kappaB activation pathway by polyphenols in human intestinal Caco-2 cells. Br. J. Nutr. 2008, 100, 542-551. [CrossRef] [PubMed]

86. Damiano, S.; Sasso, A.; De Felice, B.; Di Gregorio, I.; La Rosa, G.; Lupoli, G.A.; Belfiore, A.; Mondola, P.; Santillo, M. Quercetin Increases MUC2 and MUC5AC Gene Expression and Secretion in Intestinal Goblet Cell-Like LS174T via PLC/PKC $\alpha /$ ERK1-2 Pathway. Front. Physiol. 2018, 9, 357. [CrossRef] [PubMed]

87. Xiao, J.; Zhang, R.; Wu, Y.; Wu, C.; Jia, X.; Dong, L.; Liu, L.; Chen, Y.; Bai, Y.; Zhang, M. Rice Bran Phenolic Extract Protects against Alcoholic Liver Injury in Mice by Alleviating Intestinal Microbiota Dysbiosis, Barrier Dysfunction, and Liver Inflammation Mediated by the Endotoxin-TLR4-NF-кB Pathway. J. Agric. Food Chem. 2020, 68, 1237-1247. [CrossRef]

88. Wu, B.; Bhatnagar, R.; Indukuri, V.V.; Chopra, S.; March, K.; Cordero, N.; Chopra, S.; Reddivari, L. Intestinal Mucosal Barrier Function Restoration in Mice by Maize Diet Containing Enriched Flavan-4-Ols. Nutrients 2020, 12, 896. [CrossRef]

89. Ferrari, D.; Cimino, F.; Fratantonio, D.; Molonia, M.S.; Bashllari, R.; Busa, R.; Saija, A.; Speciale, A. Cyanidin-3-O-Glucoside Modulates the In Vitro Inflammatory Crosstalk between Intestinal Epithelial and Endothelial Cells. Mediat. Inflamm. 2017, 2017, 3454023. [CrossRef]

90. He, S.; Guo, Y.; Zhao, J.; Xu, X.; Wang, N.; Liu, Q. Ferulic Acid Ameliorates Lipopolysaccharide-Induced Barrier Dysfunction via MicroRNA-200c-3p-Mediated Activation of PI3K/AKT Pathway in Caco-2 Cells. Front. Pharmacol. 2020, 11. [CrossRef]

91. Zhang, Z.; Tang, H.; Chen, P.; Xie, H.; Tao, Y. Demystifying the manipulation of host immunity, metabolism, and extraintestinal tumors by the gut microbiome. Signal Transduct. Target. Ther. 2019, 4, 41. [CrossRef]

92. Guinane, C.M.; Cotter, P.D. Role of the gut microbiota in health and chronic gastrointestinal disease: Understanding a hidden metabolic organ. Ther. Adv. Gastroenterol. 2013, 6, 295-308. [CrossRef] [PubMed]

93. Rinninella, E.; Raoul, P.; Cintoni, M.; Franceschi, F.; Miggiano, G.A.D.; Gasbarrini, A.; Mele, M.C. What is the Healthy Gut Microbiota Composition? A Changing Ecosystem across Age, Environment, Diet, and Diseases. Microorganisms 2019, 7, 14. [CrossRef] [PubMed]

94. Ozdal, T.; Sela, D.A.; Xiao, J.; Boyacioglu, D.; Chen, F.; Capanoglu, E. The Reciprocal Interactions between Polyphenols and Gut Microbiota and Effects on Bioaccessibility. Nutrients 2016, 8, 78. [CrossRef]

95. Corrêa, T.A.F.; Rogero, M.M.; Hassimotto, N.M.A.; Lajolo, F.M. The Two-Way Polyphenols-Microbiota Interactions and Their Effects on Obesity and Related Metabolic Diseases. Front. Nutr. 2019, 6, 188. [CrossRef]

96. Hiippala, K.; Jouhten, H.; Ronkainen, A.; Hartikainen, A.; Kainulainen, V.; Jalanka, J.; Satokari, R. The Potential of Gut Commensals in Reinforcing Intestinal Barrier Function and Alleviating Inflammation. Nutrients 2018, 10, 988. [CrossRef] [PubMed]

97. Lu, K.; Mahbub, R.; Fox, J.G. Xenobiotics: Interaction with the Intestinal Microflora. ILAR J. 2015, 56, 218-227. [CrossRef] [PubMed]

98. Hasan, N.; Yang, H. Factors affecting the composition of the gut microbiota, and its modulation. PeerJ 2019, 7, e7502. [CrossRef]

99. Roopchand, D.E.; Carmody, R.N.; Kuhn, P.; Moskal, K.; Rojas-Silva, P.; Turnbaugh, P.J.; Raskin, I. Dietary Polyphenols Promote Growth of the Gut Bacterium Akkermansia muciniphila and Attenuate High-Fat Diet-Induced Metabolic Syndrome. Diabetes 2015, 64, 2847-2858. [CrossRef]

100. Ma, W.; Chen, J.; Meng, Y.; Yang, J.; Cui, Q.; Zhou, Y. Metformin Alters Gut Microbiota of Healthy Mice: Implication for Its Potential Role in Gut Microbiota Homeostasis. Front. Microbiol. 2018, 9, 1336. [CrossRef]

101. Kristek, A.; Wiese, M.; Heuer, P.; Kosik, O.; Schär, M.Y.; Soycan, G.; Alsharif, S.; Kuhnle, G.G.C.; Walton, G.; Spencer, J.P.E. Oat bran, but not its isolated bioactive $\beta$-glucans or polyphenols, have a bifidogenic effect in an in vitro fermentation model of the gut microbiota. Br. J. Nutr. 2019, 121, 549-559. [CrossRef] [PubMed]

102. Pham, T.; Teoh, K.T.; Savary, B.J.; Chen, M.-H.; McClung, A.; Lee, S.-O. In Vitro Fermentation Patterns of Rice Bran Components by Human Gut Microbiota. Nutrients 2017, 9, 1237. [CrossRef]

103. Tao, W.; Zhang, Y.; Shen, X.; Cao, Y.; Shi, J.; Ye, X.; Chen, S. Rethinking the Mechanism of the Health Benefits of Proanthocyanidins: Absorption, Metabolism, and Interaction with Gut Microbiota. Compr. Rev. Food Sci. Food Saf. 2019, 18, 971-985. [CrossRef]

104. Ramos-Romero, S.; Hereu, M.; Molinar-Toribio, E.; Almajano, M.P.; Méndez, L.; Medina, I.; Taltavull, N.; Romeu, M.; Nogués, M.R.; Torres, J.L. Effects of the combination of $\omega-3$ PUFAs and proanthocyanidins on the gut microbiota of healthy rats. Food Res. Int. 2017, 97, 364-371. [CrossRef] 
105. Déprez, S.p.; Brezillon, C.; Rabot, S.; Philippe, C.; Mila, I.; Lapierre, C.; Scalbert, A. Polymeric Proanthocyanidins Are Catabolized by Human Colonic Microflora into Low-Molecular-Weight Phenolic Acids. J. Nutr. 2000, 130, 2733-2738. [CrossRef]

106. Kuhn, P.; Kalariya, H.M.; Poulev, A.; Ribnicky, D.M.; Jaja-Chimedza, A.; Roopchand, D.E.; Raskin, I. Grape polyphenols reduce gut-localized reactive oxygen species associated with the development of metabolic syndrome in mice. PLoS ONE 2018, 13, e0198716. [CrossRef]

107. Roager, H.M.; Vogt, J.K.; Kristensen, M.; Hansen, L.B.S.; Ibrügger, S.; Mærkedahl, R.B.; Bahl, M.I.; Lind, M.V.; Nielsen, R.L.; Frøkiær, H.; et al. Whole grain-rich diet reduces body weight and systemic low-grade inflammation without inducing major changes of the gut microbiome: A randomised cross-over trial. Gut 2019, 68, 83. [CrossRef]

108. Kopf, J.C.; Suhr, M.J.; Clarke, J.; Eyun, S.I.; Riethoven, J.M.; Ramer-Tait, A.E.; Rose, D.J. Role of whole grains versus fruits and vegetables in reducing subclinical inflammation and promoting gastrointestinal health in individuals affected by overweight and obesity: A randomized controlled trial. Nutr. J. 2018, 17, 72. [CrossRef] [PubMed]

109. Vanegas, S.M.; Meydani, M.; Barnett, J.B.; Goldin, B.; Kane, A.; Rasmussen, H.; Brown, C.; Vangay, P.; Knights, D.; Jonnalagadda, S.; et al. Substituting whole grains for refined grains in a 6-wk randomized trial has a modest effect on gut microbiota and immune and inflammatory markers of healthy adults. Am. J. Clin. Nutr. 2017, 105, 635-650. [CrossRef] [PubMed]

110. Gamel, T.H.; Abdel-Aal, E.-S.M.; Tucker, A.J.; Pare, S.M.; Faughnan, K.; O’Brien, C.D.; Dykun, A.; Rabalski, I.; Pickard, M.; Wright, A.J. Consumption of whole purple and regular wheat modestly improves metabolic markers in adults with elevated high-sensitivity C-reactive protein: A randomised, single-blind parallel-arm study. Br. J. Nutr. 2020, 124, 1179-1189. [CrossRef] [PubMed]

111. Wang, Q.; Han, P.; Zhang, M.; Xia, M.; Zhu, H.; Ma, J.; Hou, M.; Tang, Z.; Ling, W. Supplementation of black rice pigment fraction improves antioxidant and anti-inflammatory status in patients with coronary heart disease. Asia Pac. J. Clin. Nutr. 2007, 16 (Suppl. 1), 295-301. [PubMed] 